\title{
Treasury Single Account: Concept, Design, and Implementation Issues
}

Sailendra Pattanayak and Israel Fainboim 


\title{
IMF Working Paper
}

Fiscal Affairs Department

\section{Treasury Single Account: Concept, Design and Implementation Issues Prepared by Sailendra Pattanayak and Israel Fainboim}

Authorized for distribution by Marco Cangiano and Michel Lazare

May 2010

\begin{abstract}
A treasury single account (TSA) is an essential tool for consolidating and managing governments' cash resources, thus minimizing borrowing costs. In countries with fragmented goverment banking arrangements, the establishment of a TSA should receive priority in the public financial management reform agenda. Drawing on the lessons of the Fund's work in several countries in establishing a TSA, this paper explains its concept, essential features, and potential benefits. It also presents alternative models and approaches for designing a TSA that take into account specific country contexts as well as the preconditions and desirable sequencing for its successful implementation. Finally, the paper includes country examples from different regions in support of the analysis and recommendations.
\end{abstract}

\section{This Working Paper should not be reported as representing the views of the IMF.} The views expressed in this Working Paper are those of the author(s) and do not necessarily represent those of the IMF or IMF policy. Working Papers describe research in progress by the author(s) and are published to elicit comments and to further debate.

JEL Classification Numbers:

Keywords: treasury single account, TSA, banking arrangement, cash management, liquidity management, public financial management, treasury management, transaction processing

Author's E-Mail Address: spattanayak@imf.org; ifainboim@imf.org 


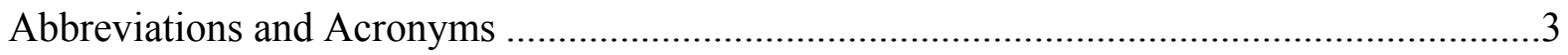

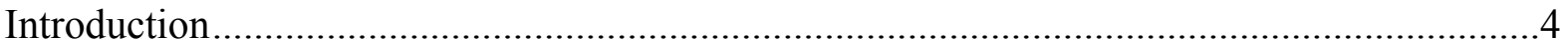

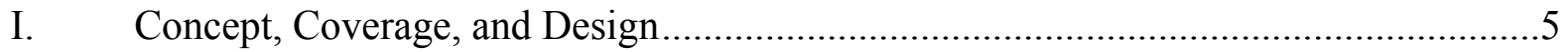

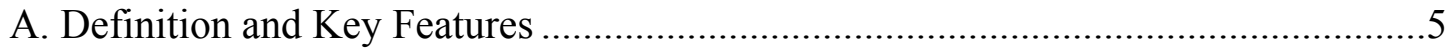

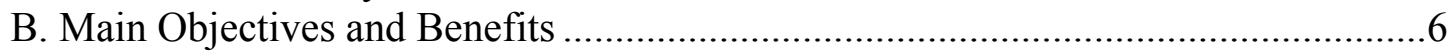

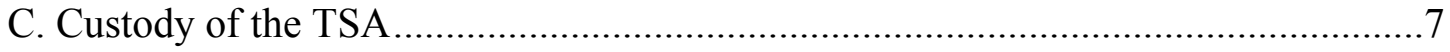

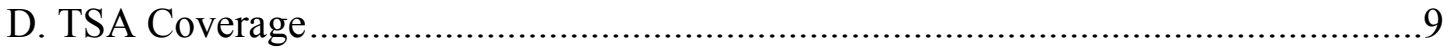

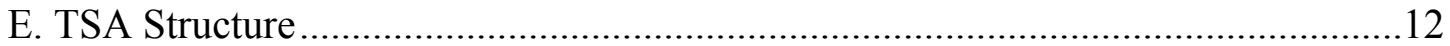

F. Transaction Processing under a TSA System .................................................... 15

II. Receipts, Payments, and Accounting Processes under a TSA System ......................19

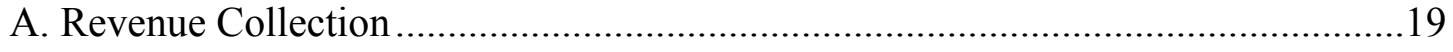

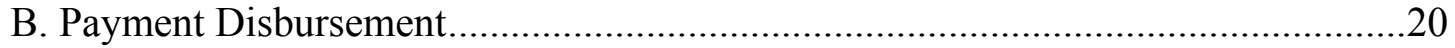

C. Accounting Through a Treasury Ledger System ................................................24

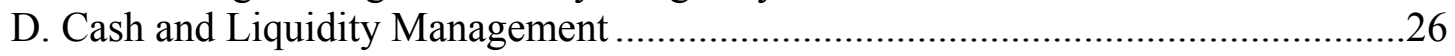

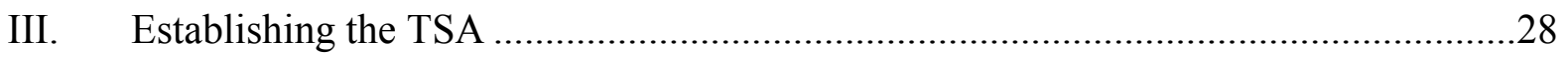

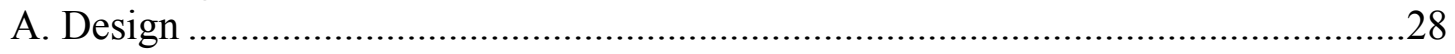

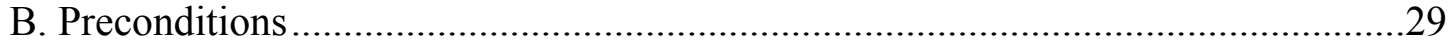

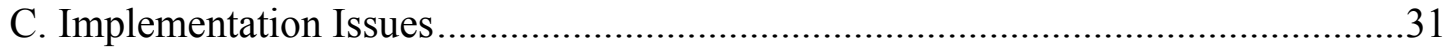

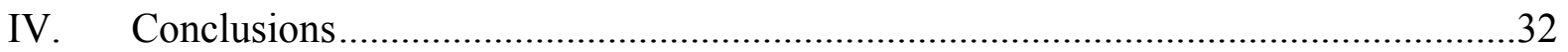

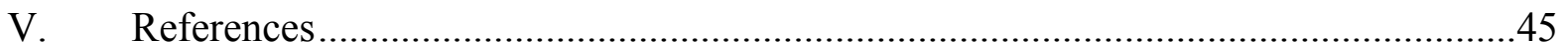

\section{Boxes}

1. Integrating Donor Funds Within the TSA .............................................................. 12

2. Various Types of Bank Accounts under a TSA System .........................................14

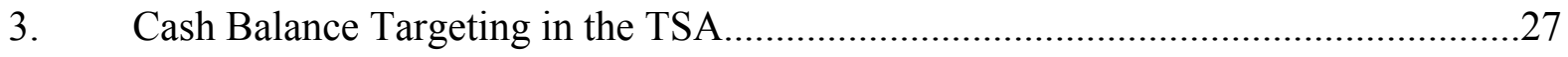

Appendixes

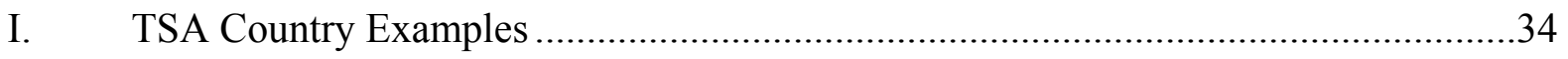

II. Interbank Payment and Settlement Systems .......................................................44 


\section{AbBreviations AND ACRONYMS}

$\begin{array}{ll}\text { ACH } & \text { Automated Clearing House } \\ \text { EBF } & \text { Extrabudgetary Fund } \\ \text { ECA } & \text { Eastern Europe and Central Asian Countries } \\ \text { EFT } & \text { Electronic Fund Transfer } \\ \text { FAD } & \text { Fiscal Affairs Department } \\ \text { GFSM } & \text { Government Finance Statistics Manual } \\ \text { IFMIS } & \text { Integrated Financial Management Information System } \\ \text { LIC } & \text { Low-Income Country } \\ \text { LVPS } & \text { Large Value Payment Systems } \\ \text { MoF } & \text { Ministry of Finance } \\ \text { OECD } & \text { Organization for Economic Cooperation and Development } \\ \text { PFM } & \text { Public Financial Management } \\ \text { PO } & \text { Payment Order } \\ \text { RTGS } & \text { Real Time Gross Settlement System } \\ \text { SOE } & \text { State-Owned Enterprise } \\ \text { STP } & \text { Straight Through Processing } \\ \text { SVPS } & \text { Small Value Payment Systems } \\ \text { TGL } & \text { Treasury General Ledger } \\ \text { TSA } & \text { Treasury Single Account } \\ \text { ZBA } & \text { Zero-Balance Account }\end{array}$




\section{INTRODUCTION $^{1}$}

Government banking arrangements are an important factor for efficient management and control of government's cash resources. Such banking arrangements should be designed to minimize the cost of government borrowing and maximize the opportunity cost of cash resources. This requires ensuring that all cash received is available for carrying out government's expenditure programs and making payments in a timely fashion. Many emerging market and low-income countries have fragmented systems for handling government receipts and payments. In these countries, the ministry of finance/treasury lacks a unified view and centralized control over government's cash resources. As a result, this cash lies idle for extended periods in numerous bank accounts held by spending agencies while the government continues to borrow to execute its budget.

A government lacking effective control over its cash resources can pay for its institutional deficiencies in multiple ways. First, idle cash balances in bank accounts often fail to earn market-related remuneration. Second, the government, being unaware of these resources, incurs unnecessary borrowing costs on raising funds to cover a perceived cash shortage. Third, idle government cash balances in the commercial banking sector are not idle for the banks themselves, and can be used to extend credit. Draining this extra liquidity through open market operations also imposes costs on the central bank.

Establishing a unified structure of government bank accounts via a treasury single account (TSA) will solve these problems, improving cash management and control. It should, therefore, receive priority in any public financial management (PFM) reform agenda. A TSA also facilitates better fiscal and monetary policy coordination as well as better reconciliation of fiscal and banking data, which in turn improves the quality of fiscal information. Finally, the establishment of an effective TSA significantly reduces the debt servicing costs.

This paper, which is based on FAD's extensive experience in providing technical assistance on government banking arrangements, discusses the rationale and strategy for establishing a TSA in countries with fragmented government banking arrangements. The paper first discusses the concept of a TSA, its objectives and benefits, followed by a description of alternative TSA models and operations depending on institutional structures. Finally, the paper proposes a sequenced strategy for establishing a TSA, including the preconditions to be met.

\footnotetext{
${ }^{1}$ This working paper has benefited from peer review by M. Cangiano, M. Lazare, R. Allen, D. Radev, J. Gardner, I. Lienert, and T. Prakash. Helpful comments were also received from other FAD/IMF colleagues and from M. Williams (FAD consultant).
} 


\section{ConcePt, COVERAge, AND Design}

\section{A. Definition and Key Features}

\section{A TSA is a unified structure of government bank accounts that gives a consolidated} view of government cash resources. Based on the principle of unity of cash and the unity of treasury, a TSA is a bank account or a set of linked accounts through which the government transacts all its receipts and payments. The principle of unity follows from the fungibility of all cash irrespective of its end use. While it is necessary to distinguish individual cash transactions for control and reporting purposes, this purpose is achieved through the accounting system and not by holding/depositing cash in transaction specific bank accounts. This enables the treasury to delink management of cash from control at a transaction level.

\section{A full-fledged TSA shares three essential features:}

- $\quad$ First, the government banking arrangement should be unified, to enable ministry of finance (Mof) (or treasury) oversight of government cash flows in and out of these bank accounts. A unified structure of government bank accounts allows complete fungibility of all cash resources, including on a real-time basis if electronic banking is in place. The TSA structure can contain ledger sub-accounts in a single banking institution (not necessarily a central bank), and can accommodate external zerobalance accounts (ZBAs) in a number of commercial banks.

- $\quad$ Second, no other government agency operates bank accounts outside the oversight of the treasury. Options for accessing and operating the TSA are mainly dependent upon institutional structures and payment settlement systems (see the section on Transaction Processing under a TSA System).

- $\quad$ Third, the consolidation of government cash resources should be comprehensive and encompass all government cash resources, both budgetary and extra-budgetary. This means that all public monies ${ }^{2}$ irrespective of whether the corresponding cash flows are subject to budgetary control or not (e.g., in the case of reserve funds, earmarked funds and other off-budget/extrabudgetary funds) should be brought under the control of the TSA. ${ }^{3}$ The cash balance in the TSA main account is maintained at a level

\footnotetext{
${ }^{2}$ For a definition of public monies, see the section on TSA Coverage.

${ }^{3}$ Some funds, notably those controlled by donors, and loans from multilateral institutions, are more difficult to integrate into the TSA. However, there is an observed trend of donors agreeing to various arrangements to integrate their aid flows with the TSA in several countries (see the section on TSA Coverage).
} 
sufficient to meet the daily operational requirements of the government (sometimes together with an optional contingency, or buffer/reserve to meet unexpected fiscal volatility). ${ }^{4}$

\section{Establishing a TSA usually requires a legal basis to ensure its robustness and stability.} Being legally recognized is thus a precondition that is particularly important in those countries where the "presumed" autonomy of some institutions is an obstacle to the implementation of a TSA.

\section{B. Main Objectives and Benefits}

\section{The primary objective of a TSA is to ensure effective aggregate control over} government cash balances. The consolidation of cash resources through a TSA arrangement facilitates government cash management by minimizing borrowing costs. ${ }^{5}$ In the absence of a TSA, idle balances are maintained in several bank accounts. ${ }^{6}$ Effective aggregate control of cash is also a key element in monetary and budget management.

There are other objectives for setting up a TSA. They include: minimizing transaction costs during budget execution, notably by controlling the delay in the remittance of government revenues (both tax and nontax) by collecting banks, and making rapid payments of government expenses; facilitating reconciliation between banking and accounting data; efficient control and monitoring of funds allocated to various government agencies; and facilitating better coordination with the monetary policy implementation.

\section{The benefits of a TSA flow from its objectives:}

- Allows complete and timely information on government cash resources. In countries with advanced payment and settlement systems and an Integrated Financial Management Information System (IFMIS) with adequate interfaces with the banking system, this information will be available in real time. As a minimum, complete updated balances should be available daily.

\footnotetext{
${ }^{4}$ The TSA arrangement needs to ensure that treasury-related revenue and disbursement floats in the banking sector are kept at the minimum level.

${ }^{5}$ This is achieved through lower costs of borrowing (to finance public expenditure) and higher investment returns (from surplus government cash). For a detailed discussion on cash management related issues, see the FAD Technical Manual on Modernizing Cash Management by Ian Lienert.

${ }^{6}$ In many countries where line ministries have cash holding accounts at the central bank, the treasury does not perform daily clearing of the balances in these accounts and despite a positive balance with the central bank, the government might have to borrow from the financial markets to meet its day-to-day cash needs. Therefore, daily consolidation of cash balances is also needed even when line ministries' accounts are held with the central bank.
} 
- Improves appropriation control. The TSA ensures that the MoF has full control over budget allocations, and strengthens the authority of the budget appropriation. When separate bank accounts are maintained, the result is often a fragmented system, where funds provided for budgetary appropriations are augmented by additional cash resources that become available through various creative, often extrabudgetary, measures.

- Improves operational control during budget execution. When the treasury has full information about cash resources, it can plan and implement budget execution in an efficient, transparent, and reliable manner. The existence of uncertainty regarding whether the treasury will have sufficient funds to finance programmed expenditures may lead to sub-optimal behavior by budget entities, such as exaggerating their estimates for cash needs or channeling expenditures through off-budget arrangements.

- $\quad$ Enables efficient cash management. A TSA facilitates regular monitoring of government cash balances. It also enables higher quality cash outturn analysis to be undertaken (e.g., identifying causal factors of variances and distinguishing causal factors from random variations in cash balances).

- $\quad$ Reduces bank fees and transaction costs. Reducing the number of bank accounts results in lower administrative cost for the government for maintaining these accounts, including the cost associated with bank reconciliation, and reduced banking fees.

- $\quad$ Facilitates efficient payment mechanisms. A TSA ensures that there is no ambiguity regarding the volume or the location of the government funds, and makes it possible to monitor payment mechanisms precisely. It can result in substantially lower transaction costs because of economies of scale in processing payments. The establishment of a TSA is usually combined with elimination of the "float" in the banking and the payment systems, and the introduction of transparent fee and penalty structures for payment services. Many governments have achieved substantial reductions in their real cost of banking services by introducing a TSA.

- Improves bank reconciliation and quality of fiscal data. A TSA allows for effective reconciliation between the government accounting systems and cash flow statements from the banking system. This reduces the risk of errors in reconciliation processes, and improves the timeliness and quality of the fiscal accounts.

- Lowers liquidity reserve needs. A TSA reduces the volatility of cash flows through the treasury, thus allowing it to maintain a lower cash reserve/buffer to meet unexpected fiscal volatility.

\section{Custody of the TSA}

As the central bank acts as the fiscal agent of the government, the custody of the TSA in most countries is with the central bank, although in theory, the main account of a TSA 
system may also be held at a commercial bank. In fact, there is no realistic alternative for economies without a well developed commercial banking system. In practice, the government banking arrangements may consist of several bank accounts which can be at both the central bank and commercial banks. However, the balances in commercial banks should be cleared every day and all government cash balances should be consolidated in one central account— the TSA main account—of the treasury at the central bank. There are also instances, particularly in Latin American countries (Appendix I), where a large publiclyowned commercial bank operates the TSA.

\section{Locating the TSA at the central bank offers several advantages:}

- $\quad$ Provides a safe haven for government cash deposits which minimizes credit risk exposure.

- $\quad$ Aids the efficient management of government liquidity, and facilitates the central bank's coordination of its monetary policy operations in managing liquidity in the economy with government's cash and debt management functions.

- Can facilitate cost effective banking arrangements and speedy settlements (it might be possible to negotiate with the central bank to act as the clearing house for government operations, which may speed settlement).

- $\quad$ Allows for clarity of banking arrangements and remuneration policies between the treasury and the central bank (a service level agreement is normally negotiated to clarify obligations and responsibilities when the central bank acts as the clearing house for government operations).

In many cases, the central bank, while maintaining the TSA, may not necessarily maintain bank accounts for agency-specific transactions. In these instances, it is regarded as inappropriate for the central bank to undertake the government's retail banking transactions, particularly as the government is usually its only direct customer. This is a task more effectively and efficiently performed by the commercial banks. Indeed, in at least one country - New Zealand - the entire daily retail transactions of the TSA are performed at a commercial bank with only a single nightly sweep of the balance going into the government account at the central bank. In competitive bidding for this business, the central bank has stated that it has no intention to play a role in retail banking.

Technological changes and recent innovations in banking practices have facilitated the operation of a TSA for government transactions. Developments in electronic banking and communication systems, including payment clearing systems and interbank settlement 
systems — such as the Real Time Gross Settlement System ${ }^{7}$ (RTGS) — have enabled the banking sector to provide single-window banking services to clients (Appendix II). Such facilities are used by private firms whose operations spread across large geographical areas. Centralized cash and accounts management takes place using facilities offered by the commercial banking sector. ${ }^{8}$

\section{TSA Coverage}

Delineating the boundary of a TSA is an important issue, and needs to be carefully considered in light of each country's institutional and legal/regulatory framework. In defined circumstances, there could be a case for maintaining some bank accounts that cannot be fully integrated into the TSA. For example, there are situations where geographical factors or the non-availability of banking facilities preclude the use of a TSA.

\section{At a minimum, the TSA should cover all central government entities and their}

transactions. These include accounts managed by social security funds and other trust funds, extra-budgetary funds (EBFs), and autonomous government entities, and loans from the multilateral institutions and donor aid resources. A TSA could also be extended, in theory at least, to include subnational levels of government and other public institutions through the use of correspondent accounts. ${ }^{9}$ Even when the central TSA does not cover subnational governments in a federal system, TSAs should be established at each subnational government level.

\section{Extending TSA coverage may be challenging, and the following issues need to be considered. In particular:}

- $\quad$ Does the government have the legal right to use, even temporarily, the surplus cash available in the social security, pension, and other trust funds to ensure cash fungibility for meeting its short-term cash needs, given that these resources are only managed by it as a trustee? ${ }^{10}$

\footnotetext{
${ }^{7}$ RTGS is used in advanced banking systems to settle payments as they occur.

${ }^{8}$ This arrangement enables a particular client firm to pool together (or credit) all its sales revenues (which may be realized by many units that are distributed geographically) and cumulate all their expenditure debits into just one account with the designated bank while the latter provides retail banking services to the firm's operational units irrespective of their location. This is aimed primarily at reducing idle cash, while ensuring that there is enough liquidity to pay for payment obligations over a foreseeable period.

${ }^{9}$ The various types of accounts under a TSA arrangement, including the correspondent account, are defined in the next section.

${ }^{10}$ There is no point in extending the TSA coverage if cash fungibility is not ensured, the use of cash surpluses being a prerequisite to an efficient TSA. However, the fungibility of cash should not limit the ability of the TSA correspondent (such as a trust fund) to make use of its own resources.
} 
- $\quad$ Is there a risk that the government may use the cash reserves in such trust funds to finance short-term budget deficits and overlook long-term liabilities and statutory obligations, e.g., to make pension payments?

- Does an EBF have separate legal status and/or a claim to operational autonomy, thus making a case for its operation outside the TSA?

It has become international good practice to include as many government-controlled trust funds and EBFs within the TSA as legally possible. The main argument is that the government is - or should be - considered to have the highest creditworthiness in the country, and that an alternative place to hold trust fund assets is thus sub-optimal. Indeed, many countries have laws which insist that certain trust assets can only be invested in government obligations. As long as the government can clearly demonstrate that its accounting systems are fully reliable, and capable of accurately distinguishing trust assets in the ledger accounts, there should be no compelling reason to exclude trust funds from the TSA. Including an EBF within the TSA may be difficult to achieve in cases where it has a separate legal status, or has a public standing (e.g., health funds). Although an indirect approach to bringing them under the TSA coverage, e.g., through the use of entity-specific correspondent accounts, may be appropriate in such cases, a balance needs to be struck between such entities/EBFs' legitimate claim to autonomy (in their operations) and the potential costs/risks arising from fragmented management of public funds.

If mutually agreed, one TSA for both central and subnational governments could be set up, but it would require a well developed accounting system and adequate checks and balances to prevent abuse. Given that subnational governments are generally autonomous entities (particularly in a federal system), their inclusion in a TSA will probably involve an agreement to remunerate their surplus resources. If such agreement involves an obligation to finance the short-term liquidity needs of subnational governments, it could increase the fiscal risks for the central government, which manages the TSA. However, if the arrangement is considered desirable and agreed upon, setting up one TSA for the central and subnational governments could also be done through the use of correspondent accounts. Although this has the advantage of consolidating the surpluses and deficits of all correspondent governments participating in the TSA system and, therefore, helps smooth out the overall gap between cash inflows and outflows in the general government sector and to that extent the cost of general government borrowing is minimized, the system should not be abused by the central government to finance its deficits at the cost of the subnational governments.

Including public corporations (as defined in GFSM 2001) in the TSA is generally not advisable, because it could limit their operational independence and blur the boundary between the government sector and the broader public sector. Public corporations provide market-based goods and services and including them in the TSA could hamper their autonomy to implement commercially oriented strategies. Also, they usually possess treasury units (with capable personnel) that handle cash resources efficiently. However, if a public 
corporation is discharging a government function, it should be designated as a government unit (in line with the definition of government sector in the GFSM 2001) and its activities and resources should be integrated with the budget and TSA, respectively.

\section{Covering donor funds within TSA}

It is still quite common, particularly in low-income countries, for donors and external loan providers to require the government to manage their funds through separate commercial bank accounts and not through a TSA. Although this practice has contributed to a fragmentation in the management of government cash resources (and in the budget process itself), the donors/lenders are not likely to change their behavior unless and until their fiduciary concerns are adequately addressed ${ }^{11}$ However, in line with the donors' commitment under the Paris Declaration to use country PFM systems, the government should encourage official donors to integrate their resources into the TSA to the extent possible. ${ }^{12}$

There are three possible options for integrating donor funds within the TSA (Box 1 provides examples of the second and third options):

- Converting donors' funds into local currency on transfer to the TSA main account (best option). Under this option, the TSA system could identify the flow of funds from individual donors used to finance specific projects. For example, this could be done through ledger sub-accounts within a TSA main account. This, being a singlecurrency TSA, is technically easier to manage.

- $\quad$ Opening separate foreign currency sub-accounts within the TSA. There could be one account for each foreign currency, or one for each of the main donor currencies. The government's accounts would still be reported in local currency, converting the foreign currency amounts at the relevant exchange rate.

- Maintaining foreign currency accounts outside the TSA, but bringing the flows within the accounting system. This option, however, weakens the concept of the TSA, and requires additional administrative processes. Nevertheless, it enables full accounting and reporting of donor flows and their utilization.

\footnotetext{
${ }^{11}$ In particular, the PFM system should address the following concerns of donors to convince them to bring their funds under a TSA arrangement: (i) assurance for use of donor aid on specific projects (or non-diversion of funds); (ii) some ring-fencing to avoid liquidity problems (and ensure timely payments during execution of donor-funded projects); (iii) minimizing exposure to exchange related fluctuations/losses in the value of donor aid (particularly when the currency exchange rate regime is volatile); and (iv) reliability of controls (in managing donors' funds) and information produced by the national PFM system.

${ }^{12}$ The Paris Declaration of 2005 encourages the integration of donor funds into the countries' PFM systems, which include the TSA.
} 


\section{Box 1. Integrating Donor Funds Within the TSA}

Mozambique. The current arrangement in Mozambique is an example of the second option discussed above. Following the implementation of an integrated financial management system (called e-SISTAFE), the government has a more effective tool to monitor the use of donor funds. The emergence of this new tool has increased the willingness of Mozambique's development partners to provide funding in the form of general budget support instead of using exclusively sector-specific or project-specific financing. The e-SISTAFE has also enabled the government to link donor funding to specific projects and track and report on project-specific disbursements. The government recently developed a separate foreign currency TSA (CUT-ME) in addition to the domestic currency TSA (CUT-MN). This is a first step to full integration of donor-funded operations into eSISTAFE. Nonetheless, some donors have concerns about the internal controls and safeguards provided by eSISTAFE and the reliability of the reports generated by the system, and have chosen to continue financing their projects outside the TSA. Also, a full integration of both CUT-MN (in domestic currency) and CUT-ME (in foreign currency) is yet to be achieved.

West Bank and Gaza. The arrangement in West Bank and Gaza conforms more or less to the third option discussed above. Although donor funds are maintained in separate bank accounts at the Arab Bank, the payments out of these accounts pass through the TSA at the Palestine Bank so that the treasury is in a position to account for and report on all such payment transactions made out of donor funds. Most of the donors, except the EU, have agreed to this arrangement.

At a minimum, donors should be encouraged to route final payments through the TSA. This could be called a "shadow TSA arrangement," since the government is able to account for and report on all donor-funded transactions as they pass through the TSA and before final payments are made to suppliers, beneficiaries, etc., from the respective donor bank accounts with commercial banks. To implement such an arrangement, there would be a need for a framework agreement covering the respective donors, government, central bank (which manages the TSA), and the respective commercial banks (managing donors' bank accounts). Such an agreement should specify the procedure, including how the donor flows and payment transactions are to be handled, including their timing.

\section{E. TSA Structure}

\section{Although there are several variants of the TSA structure that conform to the objectives discussed above, they can be broadly grouped into two categories: centralized and distributed TSA architectures. The TSA systems established in most countries fall} somewhere in between these two models (see Appendix I for various country examples), and involve various types of bank accounts as detailed in Box 2 below.

- $\quad$ A purely centralized arrangement is one in which all revenue and expenditure transactions of the government pass through a single account generally maintained with the central bank.

- $\quad$ At the other extreme, a TSA could be virtually operational even though line agencies - down to the lowest level in the organizational hierarchy - are allowed to 
retain separate transaction accounts in the banking system. However, in the latter case, balances in all transaction accounts should be swept into the TSA main account at the end of each day.

\section{The degree of decentralization of a TSA structure is linked to the authority of various entities to access and operate the government bank accounts.}

- In some countries, the TSA is composed of a single bank account (sometimes with subsidiary ledger accounts) at the central bank, which is operated either by a centralized authority (such as the treasury and its regional units) or by a number of budget institutions. In the latter case, each budget institution's transactions are tracked, accounted for, and managed through a well developed general ledger system.

- $\quad$ On the other hand, there are countries (e.g., Sweden) that have several linked bank accounts outside the TSA main account - with their balances automatically swept off at the end of each day. Individual line agencies (including deconcentrated units) are allowed to have separate transaction accounts and operate them. The TSA in this case is organized along the following lines: (i) accounts for individual spending agencies are opened either at the central bank, or with commercial banks; in both cases, the accounts must be authorized by the minister of finance; (ii) these accounts are zerobalance accounts, with money being transferred to the accounts as specific approved payments are made; (iii) the balances in the accounts are automatically swept at the end of each day (where the banking infrastructure allows daily clearing) to the TSA main account; and (iv) the central bank consolidates the balances in all the government accounts at the end of each day.

\section{Special ledger arrangements may be required in cases where the authority to operate} the government bank accounts is centralized, particularly if some entities have legal authority to retain self-generated funds, or if there are legal requirements that the funds of social security institutions be maintained separately from other funds. Sometimes, multilateral and/or bilateral donors, even if they agree to manage their aid resources through the TSA, may request that such arrangements be set up in order to ring-fence the loans or grants they provide. This would require sub-accounts within the TSA and/or the development of a comprehensive treasury ledger system to track, account for, and report on specific flows through the bank accounts. 


\section{Box 2. Various Types of Bank Accounts under a TSA System}

TSA main account. This is the treasury's account with the central bank which consolidates the government's cash position. It is the main TSA account when the TSA arrangement in a particular country consists of a set of linked accounts. Cash balances in all other linked accounts are swept into this account. In other words, all government receipts finally flow into, and all disbursements are met from, the central TSA account.

TSA subsidiary accounts or sub-accounts. These are not separate bank accounts per se (in the sense of holding individual cash balances), but are special sub-accounts within the main TSA account. This is basically an accounting arrangement to group together a set of transactions and allows the government to maintain the distinct accounting identity or ledger of its budget organizations (line ministries/agencies) effectively. A cash disbursement ceiling for each entity can be enforced against these ledgers. Balances in these accounts are netted off with the TSA main account for cash management purposes.

Transaction accounts. Sometimes government bank accounts that are justified for retail transaction banking operations are opened separately and are structured as transaction accounts. These separate transaction accounts could be opened for government entities that need transaction banking services, but do not have a direct access to the TSA main account or a subsidiary account, and/or specific category of operations (e.g., special funds). A transaction account could take the form of a zero-balance account or an imprest account. It is possible to impose a cash disbursement limit (for the concerned agency) on a particular transaction account, which could be monitored by the concerned bank. ${ }^{1}$

Zero-balance accounts (ZBAs). Where transactional accounts are necessary, these are generally opened on a zero-balance basis, i.e., end-of-the-day cash balances in these accounts are swept back into the TSA main account periodically (preferably daily). Such accounts opened in commercial banks are used for disbursements or for collection of government revenues (particularly nontax revenues). At the end of the day, all revenues collected would be deposited in the TSA. The commercial bank would honor payments of the respective agency, and would be reimbursed by the TSA overnight. ZBAs have many similarities with special credit line arrangements, where budget agencies are provided spending credits towards the amount of payments they can make within a specified period, to be reimbursed by the TSA in the central bank. A ZBA also has the benefit that it bypasses the normal interbank settlement process for each individual transaction, which is often time consuming in developing countries, and ensures same-day settlement on a net basis for all receipts and payments passing through the accounts.

Imprest accounts. These transaction accounts can hold cash up to a maximum authorized amount and are recouped from time to time. Such accounts might be necessary in some cases, particularly when there is only limited availability of interbank settlement facilities. However, the number of imprest accounts should be kept to a minimum and the strategy should be to progressively transform these accounts into zero-balance accounts. ${ }^{2}$

Transit accounts. These accounts are not meant for day-to-day transaction banking operations of government units. A transit account simply serves as a transit for eventual flow of cash into the TSA main account. Transit accounts might be necessary: (i) for major revenue streams to monitor their collection and remittance by the banking system; and (ii) to facilitate revenue sharing (formula-based sharing from a common pool of resources) between tiers of government in a federal system in line with constitutional and/or legal requirements. ${ }^{3}$

Correspondent accounts. A separate ledger account is opened for each correspondent. The correspondent entity has realtime information on the balances it maintains in the TSA. There should be safeguards to ensure that each correspondent government is provided with the funds needed to implement its own budget in a timely manner. The central bank (which maintains the accounts in the TSA) has the obligation to make payments to the extent of the balances available in a correspondent's account.

${ }^{1}$ The bank accepts the payment orders sent by spending units up to a certain limit defined by the treasury.

${ }^{2}$ In any case, cash holding imprest accounts should not be opened to bypass the normal budget execution procedure (including the required ex ante control for authorizing payments).

${ }^{3}$ This objective could also be met by developing a treasury ledger for the purpose. 
The decision as to whether-and to what extent—budget authority should be delegated to line ministries and spending units is independent of the TSA structure. The TSA is a centerpiece of treasury management in countries with very different circumstances. In many developed countries with highly decentralized budget and accounting systems, spending agencies have considerable autonomy in implementing the budget, but the end-of-the-day balances in government bank accounts are electronically swept into the TSA.

The government's banking arrangements should take into account possible impact on financial management within spending agencies and must also be cost effective. For example, it is generally advisable for the central units ${ }^{13}$ of line ministries and departments to replace a system of separate bank accounts with a single account (with or without subaccounts). But for the regional deconcentrated units of line ministries/departments, the organization of the payment system must take into account the country's context and infrastructure. ${ }^{14}$ However, imprest accounts with non-zero balances violate the TSA principle, and the use of such accounts should be actively discouraged. ${ }^{15}$

\section{F. Transaction Processing under a TSA System}

One key question is how the consolidation of cash balances through a TSA will interface with transaction processing and accounting systems, the latter being either centralized or decentralized. Issues related to cash management should not be confused with issues related to the distribution of responsibilities for accounting control and administration of the payment system. A TSA can operate with both centralized and decentralized (or deconcentrated) transaction processing and accounting control systems. However, the feasibility of implementation depends on the level of technological development of the banking sector and the government, including an IFMIS and a reliable communications network. Poor banking and technological infrastructure in some developing countries and LICs is sometimes an obstacle to combining consolidation of cash balances with decentralization of payment processing. In countries with an underdeveloped banking infrastructure, daily clearing of accounts with various banks could be more difficult than

\footnotetext{
${ }^{13}$ Spending units at the same location as the ministry/department's headquarters (i.e., the capital city) are referred here as "central units."

${ }^{14}$ Practical considerations in countries not having good communications facilities may require a limited number of additional bank accounts. The challenge here is how to achieve the best possible mode of centralizing government cash balances while ensuring the minimum disruption to the existing payment system if the latter were to continue on legal and/or institutional grounds.

${ }^{15}$ For instance, in Indonesia, the line ministries' imprest accounts - about 32,000 of them - are currently being integrated into the TSA system and balances in these accounts will be zero-balanced at end of the day. Effective procurement planning also reduces the need for imprest accounts, which are sometimes set up to pay for ad hoc procurements.
} 
daily settlement within a set of accounts at the central bank. Maintaining a large number of accounts at commercial banks could also hinder the implementation of appropriate clearing and consolidation procedures.

\section{There are two primary transaction processing models, each of which could be associated with either the centralized or distributed TSA architecture.}

- $\quad$ The first model is based on centralized transaction processing. This implies a concentration of authority at the treasury to process transactions, and access and operate the TSA. In this case, the treasury (supplemented in some countries by a network of regional treasuries) provides payment services for spending agencies and has the exclusive authority to operate the TSA, including its regional treasury subaccounts. The budget institutions submit their payment requests to the centralized authority/treasury before making payments. Such a transaction processing model could be associated with either the centralized (e.g., Brazil and France) or the distributed TSA structure (e.g., the United Kingdom). In both cases, only the centralized authority/treasury operates the TSA main account and transaction accounts. There could be separate transaction accounts for each regional treasury unit and/or individual budget institutions.

- $\quad$ The second model is associated with decentralized payment and accounting systems. In this case, each budget institution processes its own transactions during budget execution and directly operates the respective bank account under a TSA system. Such a transaction processing model could be associated with either the centralized (e.g., India, where a single bank account at the Reserve Bank of India, the central bank, is supplemented by subsidiary ledger accounts to record and control payments attributable to individual line ministries) or the distributed TSA structure (e.g., Sweden, where each decentralized budget institution has one or more transaction accounts at one more banks). Combining the options of the decentralized TSA structure and the decentralized transaction processing model would, however, require an efficient and reliable communication network and interbank settlement system for netting of balances of several transaction accounts with the TSA main account.

\section{Centralized model}

Under this model, requests for payments are prepared by individual budget agencies and sent to a central treasury payment unit for control and execution. ${ }^{16}$ The central payment unit manages the float of outstanding invoices. This model may create a useful synergy between cash management on the one hand, and expenditure control and transaction

\footnotetext{
${ }^{16}$ A centralized treasury could also have branches (e.g., local or regional treasuries).
} 
accounting on the other hand. However, the centralization of expenditure transaction processing can also lead to inefficiencies, including high transaction costs, and potential for corruption in countries where the control systems are inadequate. Another issue that needs to be considered is whether the authorization of commitments is centralized or decentralized to individual spending agencies. In the latter case, if the commitment control and payment systems are not well integrated (i.e., if commitments are entered into by spending agencies well beyond the authorized cash profile that serves as the basis to process payments when the commitments mature), payment arrears may occur.

\begin{abstract}
Although in this model the payment and accounting functions are centralized, individual spending agencies are treated as distinct accounting entities through a treasury ledger system. ${ }^{17}$ Therefore, information on the individual ledger accounts of the spending agencies (including information on their respective transactions) is maintained and controlled internally by the treasury and thus not visible to the banking system. Under this model, only the treasury central unit deals with the commercial banks, making payments from the TSA and receiving collected revenues into the TSA.
\end{abstract}

The central unit processes and records all inflows and outflows and cash balances to the appropriate ledger account. However, some part of budgetary accounting could still be the responsibility of the respective spending agencies (particularly when commitment control is decentralized) and, therefore, clear procedures should be in place to harmonize (and reconcile) the accounts maintained both by individual spending agencies and the central payment unit. ${ }^{18}$

\title{
Decentralized model
}

Under this model, individual budget agencies process and make payments directly to suppliers and account for these transactions through a TSA system. Modern technology allows electronic links between spending agencies, the central bank, the commercial banks, and the treasury. The treasury sets the cash limits - monthly or quarterly — for the total

\footnotetext{
${ }^{17}$ A double-entry accounting system (whether on a cash or accrual basis) uses a set of linked ledger accounts. In a computerized environment, individual ledger accounts are established and managed through a treasury general ledger (TGL). The concept of a treasury general ledger (or general ledger system), that is, a system where all transactions are recorded, can fit either centralized or decentralized accounting controls and payment processing systems. The TGL can also be linked with the accounting and management information systems maintained at the agency level.

${ }^{18}$ This can be done through the general ledger and agency-specific subsidiary ledgers of an IFMIS. If there is no IFMIS, the chart of accounts and accounting procedures used by the central payment unit and individual spending agencies should be harmonized. For example, to address this issue several Central Asian countries (e.g., Georgia and Uzbekistan) are developing a unified chart of accounts to be used by both the centralized treasury and individual spending units.
} 
amount of disbursements to be made by a particular budget agency, but does not control individual transactions. The authority to make commitments is granted to the budget agencies on a periodic basis (generally each quarter) by the budget office, and cash limits are set by the treasury, often on a monthly basis. ${ }^{19}$ This is a model of centralized cash control, but decentralized responsibility for commitments, payments, and accounting. This model makes the spending agency responsible for internal control and management, while keeping central control of cash through the TSA.

\section{An example of a decentralized model is one that combines TSA sub-accounts for line ministries and zero-balance accounts for individual spending agencies within each line ministry. Under this variant, the ministries/departments maintain sub-accounts of the TSA at the central bank. Various sub-accounts may be set up for different institutional types and each may have different operating rules. Cash limits should be set for each spending entity. On the other hand, individual spending agencies within a parent ministry/department have zero-balance transaction accounts authorized by the treasury, generally in commercial banks, which are automatically swept at the end of each day (if the banking sector is able to do this). Cash is transferred as specific payments are approved (or daily credit limits negotiated). At the end of the day, the central bank records the cash to the appropriate major institution sub- account in the central bank so that a balance of all government accounts incorporating the TSA can be seen.}

\section{Under the decentralized model, the process of sweeping a large number of bank accounts, especially if these are in different banks, may pose a challenge and errors may result. Daily sweepings are difficult to manage because of the staff time required to ascertain how much cash to return the following day to cover payments that, for some reason, were not processed on the expected day. To work efficiently, this model requires fast electronic clearing of payments and ideally an RTGS system.}

\section{The efficiency of each model, including its capability for immediate reporting, is dependent on the availability of revenue and expenditure information at different stages} of the budget execution cycle. In a manual environment, the centralized model would have the capability for immediate reporting on payments and expenditure. However, information on outstanding commitments and payables (which is needed for cash planning and management) may still not be available centrally if such information is maintained by respective spending agencies. In a computerized environment, particularly in cases where a comprehensive IFMIS has been implemented, tracking of transactions at different stages of

\footnotetext{
${ }^{19}$ If an institution does not have direct access to a computerized and networked accounting system, the treasury may provide the service. On the other hand, IFMIS must include automatic controls to check that transactions are within budget authority and cash limits, and reject the commitment or payment if there is insufficient authority.
} 
the budget execution cycle and reporting on them should not be a problem irrespective of whether a centralized or decentralized model is selected.

There are also other more decentralized models, which in practice cannot be considered TSA models. For instance, in some countries budget institutions maintain their own bank accounts in the central bank or a commercial bank to which cash transfers are made from the central bank. These transfers are recorded as expenditures even if payment to the final beneficiaries takes place at a later stage, implying that funds can remain in the respective institution's bank account for a significant period. Because this model permits the maintenance of idle balances in bank accounts, it is clearly not a TSA.

\section{Receipts, Payments, And Accounting Processes Under a TSA System}

Technological advancements have played an important role in changing governments' banking practices over recent decades. ${ }^{20}$ Check processing has been accelerated, and electronic payment systems expanded; the availability of electronic banking networks at commercial banks allows for very effective, virtually cost-free sweeping of balances on a daily basis.

\section{A. Revenue Collection}

In most countries, commercial banks are used for revenue collection purposes on a remuneration basis. International best practice is to have the banks transfer revenues collected to the TSA main account on the same day (eliminating one of the sources of float). The banks are remunerated on a fee-for-service, based on the number of transactions that have been processed. The fee is usually established through a competitive bidding process. ${ }^{21}$ When there are RTGS settlement systems in place that allow commercial banks to network with other banks and with the central bank, the fee can be negotiated and reduced to a small amount. In some countries, banks providing revenue remittance services are remunerated by allowing them a float for a few days. ${ }^{22}$ This remuneration system is not transparent and does not clearly indicate the cost of revenue collection services provided by banks. The banks use the free float to invest in interest-bearing securities. This process clearly distorts the TSA structure and concept.

\footnotetext{
${ }^{20}$ For instance, "the banking industry has created new products that allow depositors" access to real-time account balance information and the ability to move funds electronically" (Larson and Corinne, 2007).

${ }^{21}$ An option is to seek competitive quotations for revenue remittance services and, drawing on them, determine the unit price per electronic transaction. This rate could then be uniformly applied to all participating banks.

${ }^{22}$ For example, in Colombia the revenue collecting banks are allowed to retain the revenues for 15 days before remitting to the TSA.
} 
Chart 1 describes a simple revenue circuit. The taxpayer makes the payment to a transit account ${ }^{23}$ in a commercial bank. The funds are automatically remitted to the TSA in the central bank at regular intervals (for instance, at the end of the business day or at more frequent intervals if an RTGS is used). Each day the bank submits an account statement (ideally in electronic format to facilitate reconciliation) to the tax authority and to the treasury, which is used for reconciliations against taxpayer records (tax authority) and the TSA (MoF/treasury). As mentioned above, an RTGS could enable within-the-day transfers from taxpayers' accounts to the TSA, via commercial bank accounts.

\section{Chart 1. Revenue Circuit}

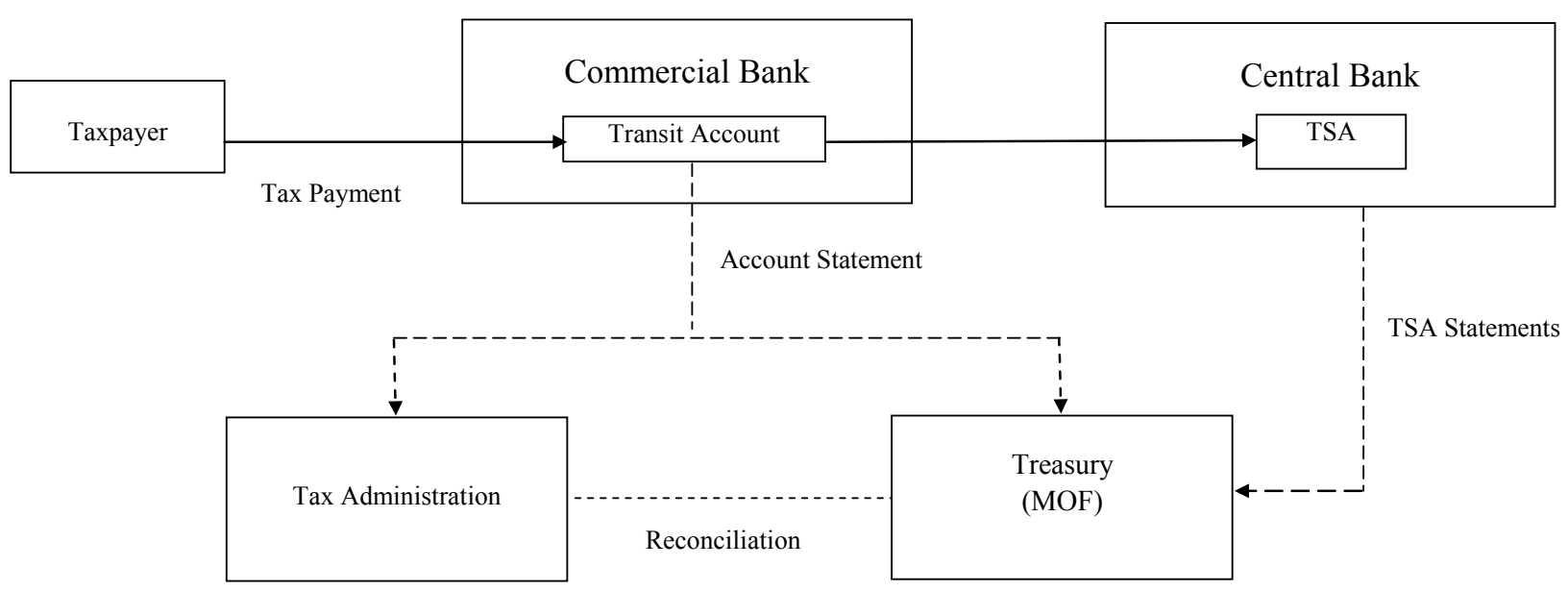

In countries where the banking system does not have a network of branches with ample coverage and the communication infrastructure is inadequate, the treasury might have to collect revenues through its regional offices. In some countries, the treasury contracts with private sector companies (non-banking companies) for the collection of government revenues in geographically dispersed areas. These difficulties significantly compromise the TSA concept but can only be improved as the electronic banking infrastructure is developed.

\section{B. Payment Disbursement}

The main objectives of a disbursement system are to pay the government's obligations in a timely and cost-effective manner, and to reduce opportunities for fraud and theft.

\footnotetext{
${ }^{23}$ Transit accounts are generally used for collecting tax revenues and zero-balance accounts are usually used for remitting nontax revenues and transferring them automatically to the TSA at designated intervals.
} 
Manual or semi-automated treasury systems imply slow payment processes. Many developing countries have very basic financial management systems and communication infrastructure, together with a manual or semi-automated (and often not integrated) treasury system and limited communication capabilities. In such countries, payment requests often go through regional or local treasury offices and are submitted for payment and settlement against the TSA. This results in slower payment processes than with fully automated systems.

A computerized treasury system (such as an IFMIS) and an advanced communication infrastructure allow electronic fund transfers from the TSA to the recipient's account, eliminating payment delays and idle balances and thus reducing operational risks. As with revenue collection, one of the objectives of the treasury should be to eliminate or shorten any delay in payments. Good international practice has been to automate the payment processes, and adopt an electronic payment system, with direct payments to the bank account of the beneficiary. Many governments offer direct deposits (of salaries, pensions, etc.) to employees' and pensioners' accounts. ${ }^{24}$ This is efficient and less prone to fraud than other options, such as payments in cash or by check.

Payment by check has advantages, but also important disadvantages. Checks provide a paper trail. However, they slow the speed of disbursements by payors, due to time delays between the issuance, encashment and clearing of a check, which also gives rise to significant check floats in some cases. There is also a high incidence of fraud related to such transactions. Writing and delivering checks is expensive and can introduce errors, creating the need for a separate reconciliation process, and affecting the effectiveness of the cash management system. Checks can also be stolen or altered. This does not mean that electronic payment systems are not potential areas for fraud and do not require fraud prevention measures such as sound internal controls, passwords, restricted access, and restricted authorization to prevent access to fund transfer initiation systems.

Some countries have adopted the practice of making large or important payments through direct bank transfer (to the beneficiaries' accounts) by the treasury, whereas smaller payments are handled by checks issued on zero-balance accounts in commercial banks, where they are settled against the TSA and reconciled. The method of direct bank transfer is often also used for payment of salaries and pensions. In such cases, the treasury agrees that a bank/financial institution deposit the funds directly into the bank accounts of an approved list of public employees (based on the payroll) and pensioners.

\footnotetext{
${ }^{24}$ In Argentina, for instance, "the government has promoted the use of debit and credit cards by offering tax incentives and by strongly promoting the use of payroll cards" (EIU, 2005, p. 16).
} 
The feasibility of a daily settlement between the ZBAs of budget institutions and the TSA main account depends upon the technology used for interbank settlements (e.g., settlements done electronically, through fax or otherwise) and the system, electronic and/or manual, used by the central bank for clearing of collections and payments with the commercial banks (Appendix II).

A procedure for centralized payments by the treasury is described in Chart 2. The spending units submit payment requests (payment order (PO)) to the treasury, which checks them against the authorized limits and processes them for payment from the TSA through one of the interbank payment systems. The funds are deposited in the recipient's account in a commercial bank.

\section{Chart 2. Centralized Payments by the Treasury from the TSA}

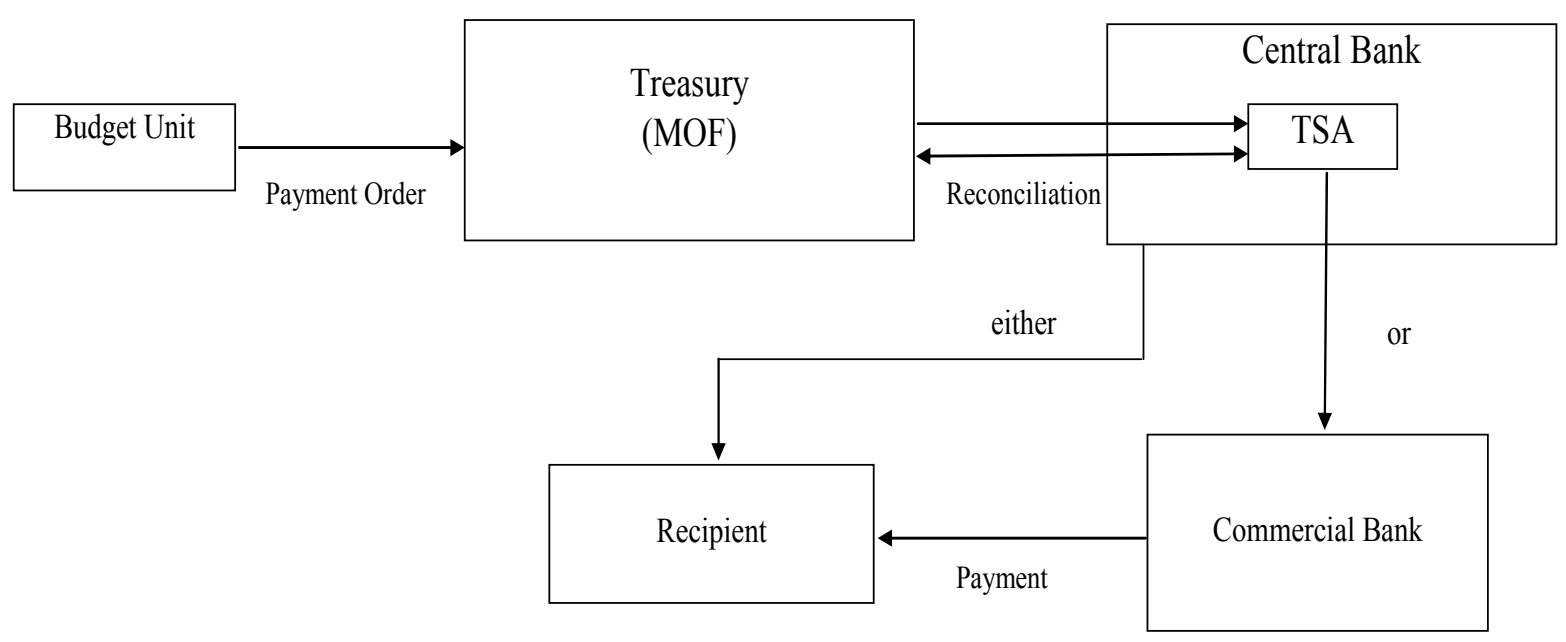

A centralized payment procedure could also be implemented through zero-balance accounts in commercial banks. A spending unit submits the POs to the treasury central unit for authorization. The treasury does not make the payment itself, but notifies the commercial bank about the cash limit it has approved on the ZBA of the spending unit. The spending unit then submits the treasury-authorized POs to the commercial bank. The bank checks the POs against the cash limits authorized by the treasury, and if the POs are within the limits, the bank makes the payment to the recipient and gets reimbursement from the TSA. The treasury reconciles the reimbursements made from the TSA with its records of approved POs. 
Under a decentralized system, the respective spending agencies verify the POs and directly submit them to the commercial banks for payments to be made from the ZBAs, as described in Chart 3 below. Although in this case the control of individual payment transactions is decentralized, the centralized cash control is enforced through total cash disbursement limits set by the treasury/MoF on each of these ZBAs. These limits are notified both to the respective commercial banks and the payment controllers in spending agencies.

\section{Chart 3. Decentralized Payments Through ZBAs}

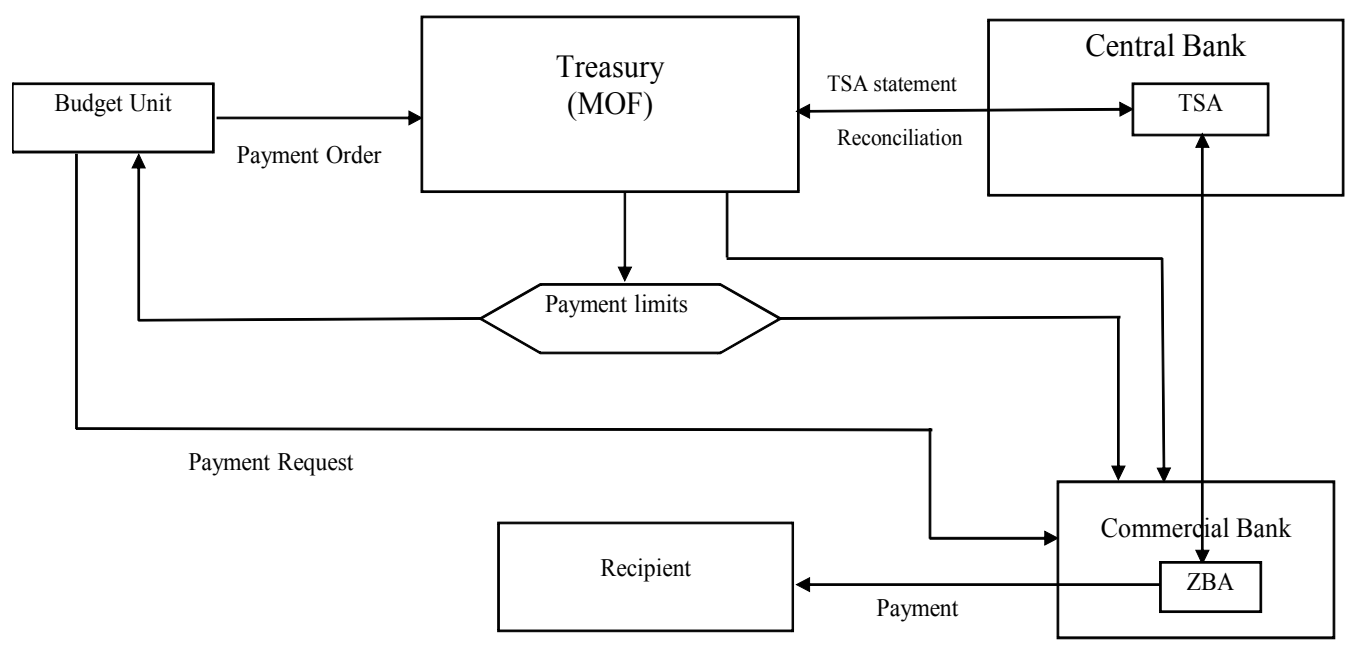

If commercial banks provide transaction banking services, strategies for obtaining payment processing and revenue remittance services from them should be carefully formulated keeping in view the reach, quality of service, and risk exposure of the commercial banking network. In cases where the authorities want the taxpayer to be able to remit taxes at any bank of his choice, the strategy for revenue remittance services would differ from that for payment processing services. For example, the remuneration of banks providing revenue remittance services could be based on the unit price per electronic transaction instead of being linked to the turnover value of transactions. ${ }^{25}$

${ }^{25}$ And penalties should be charged for delays in transfer of government funds to the TSA. 


\section{Accounting Through a Treasury Ledger System}

\section{The government accounting system should be designed to record all transactions and capture relevant information independently of the cash flows in specific bank} accounts. ${ }^{26}$ There may be problems, in practice, in achieving this result. In many countries with manual accounting systems, a comprehensive treasury ledger system does not exist and a significant part of the information required for budgetary and financial accounting purposes continues to be derived from the government's bank accounts structure such as information specific to spending agencies, budget lines, etc. If a computerized Integrated Financial Management Information System (IFMIS) is being considered, it comes with an inbuilt treasury general ledger (TGL). TGL systems typically have layers of sub-accounts for handling all types of treasury operations related to receipts, payments, financing, and surplus cash placement. ${ }^{27}$

\section{Depending upon how it is implemented, a TSA system could have implications for the accounting system. Two particular issues need to be addressed:}

- $\quad$ First, important financial information may be lost if budget agencies' bank accounts are closed as part of the implementation of a TSA. For example, in some countries the implementation of a TSA has necessitated the addition of codes providing required geographical and organizational information. The coding structure used in the chart of accounts (including that to be used in an IFMIS) should be reviewed for adequacy in the context of the implementation of the TSA.

- $\quad$ Second, the implementation of a TSA might require changes to accounting systems and processes, including the redistribution of accounting roles and responsibilities between the central treasury unit, ministries, spending agencies, etc. Depending on the structure of the TSA, either the treasury or line ministries/agencies, or both, would maintain the initial accounting records such as cash books and have bank reconciliation responsibilities. Accounting system should also be able to track and control annual appropriations and monthly/quarterly allocations to spending agencies.

\footnotetext{
${ }^{26}$ In other words, different types of cash transactions (whether receipt or disbursement of cash) passing through the same bank account may require different accounting treatments and need to be distinctively recorded through a system of linked ledger accounts.

${ }^{27}$ The TGL module of an IFMIS, therefore, must have the following capabilities: (i) recording of all payments and all transactions with cash (transfers among accounts, transfers to deposit accounts and other investment actions, transfers to the TSA main account in the central bank, etc.); (ii) continuous tracking of cash in bank accounts; (iii) transferring cash to bank accounts outside the TSA system (e.g., petty cash, salaries, pensions, etc.); (iv) reconciliation of daily postings in the TGL and associated subsidiary ledgers with the cash movements in the TSA, including daily and monthly reconciliation of bank accounts (such as ZBAs) of line agencies; and (vi) preparing summary statements of transactions for reporting and monitoring purposes.
} 
A TSA can be established without an IFMIS, but an IFMIS will enhance its efficiency. As mentioned, the advantages of working with an IFMIS include the possibility of creating in the IFMIS any number of sub-accounts that are needed for financial management purposes. The IFMIS should also provide electronic interfaces between the treasury and spending agencies on the one hand and the banking system (including commercial banks providing transaction banking services) on the other, so as to reduce transaction costs for electronic payments and revenue transmittals.

An IFMIS with a treasury general ledger (TGL) can operate under either model of transaction processing. However, the feasibility of implementation (particularly under the decentralized arrangement) would depend on the level of technological development of the banking system and the government's accounting and banking arrangements. This would also require the installation of an efficient and reliable communication network to link each and every budget institution on a real time basis to the system, reengineering existing procedures to ensure control functions in an automated environment, capacity building and training to use the system, and adhering to a well-designed system maintenance plan throughout its life cycle.

The issue of designing an appropriate interface between the TSA and the transaction processing/accounting systems, whether centralized or decentralized, should also be addressed at the conceptual design stage of an IFMIS. ${ }^{28}$ With the introduction of electronic fund transfer (EFT) in the banking sector, it would be possible to move towards direct payments from the TSA main account, especially for large value payments to suppliers, or regular large quantity transactions (such as wages).

\section{Bank reconciliation}

A TSA facilitates full reconciliation between the government accounting systems and cash flow statements from the central bank and commercial banks, usually through automated mechanisms. ${ }^{29}$ Each day, all banks involved should submit to the tax administration and the treasury bank account statements to be used for reconciliation against taxpayer records and the TGL. The expenditure data maintained by the treasury/spending units should be fully reconciled with banking transaction data. There should be reconciliation

\footnotetext{
${ }^{28}$ Please refer to the IMF FAD Technical Note and Manual on Conceptual Design of an IFMIS, by A. Khan and M. Pessoa.

${ }^{29}$ Bank reconciliation is an important element of managing and accounting for government transactions through the banking system. The benefit of reconciling the bank statement is ensuring that the amount of cash reported by the treasury (from its own books) is consistent with the amount of cash shown in the bank's records. Fiscal transparency also requires routine (normally on a monthly basis) reconciliation of bank statements with government accounting data (Manual on Fiscal Transparency, p. 55, 2007, IMF).
} 
of parallel but related streams of transaction data. First, at the agency level, checks issued should be reconciled with those paid by the banks; second, at the treasury, receipts from banks should be reconciled with the checks paid by taxpayers, and cash balances in the banks netted off against transactions by spending agencies. If adequate communication infrastructure exists, the treasury should be electronically linked with the central bank and commercial banks to enable the electronic transfer of payment instructions, the electronic receipt of bank statements, and the exchange of information for facilitating automatic bank reconciliation.

\section{Cash and Liquidity Management}

A TSA regime should be supplemented by proactive cash management. This involves forward cash planning as a precondition and implies the development of a strategy for remunerating temporary cash surpluses and financing temporary cash needs. The overall objective of effective cash management is to reduce the average cash balances of the government to a minimum level (consistent with unexpected variations from reasonably accurate forecasts), so as to avoid unnecessary borrowing and to maintain stable liquidity levels as far as possible. ${ }^{30}$

\section{Many advanced countries attempt to minimize the level of cash balances held in the TSA by actively targeting a minimum balance (Box 3). Where the treasury successfully} targets a stable cash balance in the TSA, the effect of the government's fiscal transactions is largely neutralized for money market and monetary policy purposes, therefore simplifying liquidity management operations. This can be achieved through the use of various instruments that allow the government to place surplus balances in the market or to access funds at short notice, if there is an unexpected requirement for funds. It will be difficult for many developing countries and low-income countries (LICs) to target cash balances in the absence of a developed domestic government short-term securities market, or arrangements with commercial banks to lend cash at short notice to the treasury. However, the development of an active cash balance targeting policy should be a long term objective, to be implemented when the necessary pre-conditions are in place.

Once a TSA has been established and its target balance has been set, a strategy needs to be developed for investing available surplus cash, and funding temporary cash shortfalls. The strategy should include options for both short-term and longer term investments. ${ }^{31}$ The management of surplus cash investment and short-term borrowing could

\footnotetext{
${ }^{30}$ For further discussion on this issue, please refer to the Technical Manual on Modernizing Cash Management by I. Lienert (2009).

${ }^{31}$ Options for investing idle cash balances at longer terms include: (i) interest-bearing fixed deposits of specific duration at the central bank to store cash not immediately required; (ii) interest on the treasury operational account; (iii) deposits at commercial banks; and (iv) sovereign wealth funds. The choice of approach depends mainly on how long the assets need to be retained.
} 


\section{Box 3. Cash Balance Targeting in the TSA}

Many advanced countries have introduced a system of targeting cash balances through the TSA. The instruments and methods used to achieve this vary considerably.

\section{Rough tuning vs. fine tuning}

Most countries start off with a process of "rough tuning." This essentially entails the use of treasury bills (T-bills) or other short-term borrowing instruments aimed at offsetting the impact of government cash flows (in and out of the market) on the balance sheet of the central bank. Fine tuning relies on more active policies using a greater number of instruments to accurately target daily cash balances on the TSA.

\section{In which countries has fine tuning been applied?}

In the Euro zone, the operation of monetary policy by the European Central Bank (ECB) requires member countries to manage their balances at the national central bank to a target figure - so that the potential impact of government cash flows on monetary conditions is offset within the banking sector, and does not have to be taken into account in the ECB's monetary policy operations. Other countries such as Sweden and the U.K. have adopted similar approaches.

\section{What sort of instruments is used?}

Countries use many different instruments, including T-bills and commercial bills. Some countries, such as the U.S., use special "cash management" bills, issued for debt financing purposes. If there is expected to be a significant cash outflow in, say, the following week, an additional issue of cash management bills can be made at short notice. Finetuning can be managed using a variety of instruments, including repos, collateralized deposits, and committed loan facilities at commercial banks.

\section{Some examples of target balances}

France has a daily target balance of $€ 100$ million, a relatively insignificant level when compared to the average gross intraday cash flows of over $€ 22$ billion (2006). Sweden has adopted a zero target as a matter of policy. Following a change in monetary policy operations in 2006, the U.K. has moved from a daily target of $£ 200$ million to a weekly target agreed between the U.K. Debt Management Office and the Bank of England.

be handled either by a specialized unit within the MoF or by a fiscal agency agreement with the central bank. In developing countries, MoFs/treasuries often lack the expertise required for undertaking money market operations and tend to let the central bank handle this task on their behalf. The reason is that money market operations are a usual central bank activity, performed as part of its monetary operations. As with all fiscal agency operations performed by a central bank, however, it is vital that these market transactions are transparently distinguished from any monetary policy operations. 


\section{ESTABLISHING THE TSA}

\section{A. Design}

From the preceding sections, the following key parameters influence the design of a TSA in a country-specific context:

- $\quad$ The state of development of the country's banking system, including available banking technologies and geographical coverage;

- $\quad$ The preferred degree of centralization (or decentralization) of transaction processing;

- The need for agency-specific transaction accounts;

- $\quad$ The need for transit accounts (particularly for collection of main revenue streams);

- $\quad$ The required interface between transaction processing/accounting and the TSA system;

- $\quad$ Bank reconciliation procedures;

- $\quad$ The prevailing interbank settlement and clearing systems;

- $\quad$ Required changes to the chart of accounts/treasury ledger system and associated accounting processes and procedures; and

- The availability of an IFMIS.

More specifically, the following questions/issues need to be addressed while designing a TSA and sequencing its implementation:

- Whether revenue-specific separate bank accounts should be set up for the major sources of government revenue and customs receipts. This is a normal practice in many countries with broad-based revenue collection arrangements such as the use of the commercial banking network for the purpose.

- Whether there is a need to have transit accounts other than for revenue collection.

- Whether a daily settlement between the ZBAs of budget institutions and the TSA main account would be technically feasible. As mentioned above, this would depend upon the technology used for interbank settlements and the system used by the central bank for clearing of collections and payments with the commercial banks.

- What should be the distribution of roles and responsibilities (between ministries, spending agencies, commercial banks, the central bank and the treasury) and reporting arrangement for bank reconciliation under the TSA arrangement?

- Whether there should be special arrangements - cash safes and imprests for example - for remotely located budget institutions without access to the banking network.

- What should be the appropriate interface between the TSA and the transaction processing/accounting systems, the latter being either manual or electronic?

- What specific procedures for processing, recording, and reporting of transactions need to be developed to enable the consolidation of fiscal data at agency, department, 
and whole-of-government levels once agencies' cash-holding bank accounts are closed to implement the TSA (as a consequence of which inter-departmental and inter-agency transactions will be treated as nonbank transactions)?

- What accounting arrangements need to be established to integrate the cash balances of legally constituted extrabudgetary funds into the TSA structure, and allow the government to maintain the distinct accounting identity of these funds?

- $\quad$ What would be the appropriate strategy for obtaining payment processing and revenue remittance services from commercial banks on a remuneration basis? For example, electronic direct payments to and from the TSA are common, even in developing countries where the banking infrastructure permits electronic fund transfer (EFT) operations.

\section{B. Preconditions}

Governments should take into account the preconditions for establishing a TSA. Unless these are in place, the implementation of the TSA is unlikely to be successful, as the experience of many countries demonstrates. While some of these preconditions are critical and should be addressed upfront, progress on others can take place in tandem with the introduction of the TSA. Successful implementation of a TSA also requires sound treasury systems and processes. It is, therefore, important to look at TSA and treasury reforms as one integrated package.

\section{There are at least eight key preconditions for establishing a TSA:}

- $\quad$ Preparing an inventory of existing bank accounts. In countries with a fragmented government banking arrangement, the process of establishing a TSA should start with a census of the existing bank accounts of all government entities. ${ }^{32}$ Following the census, a complete inventory of government accounts should be prepared (including their nature, type, and cash balances). This would facilitate identifying bank accounts for eventual closure/merger with the TSA.

- Political support. Establishing a TSA can require hard decisions, such as closing the existing bank accounts of budget organizations (outside treasury control), that can provoke powerful opposition. For success, a TSA reform must be explicitly and strongly supported by the highest levels of government. Cabinet decisions to initiate and reinforce the reforms are helpful.

\footnotetext{
${ }^{32}$ This is vital because in some countries an unknown number of government bank accounts are opened by ministries and other government agencies and until all are included in the TSA, its structure is incomplete. Unknown or hidden bank accounts pose particular threats to the overall objectives of the TSA concept and its associated transparency benefits.
} 
- $\quad$ Legal and regulatory requirements. The legal framework should be amended, as necessary, to allow for the establishment of the TSA. The establishment of a TSA must be accompanied by the closure of irregular bank accounts of ministries and budget units, and legal authority for opening government accounts should be vested in the MoF.

- Technological requirements. The technological feasibility and capacity of the banking system to participate in the operation of a TSA, and to report on TSA transactions, should be established. In fact, a decision on TSA could trigger the acquisition of necessary technology by the banking system as the banking services will be remuneration based.

- The existence of an interbank settlement system. This includes the development of a small payments clearing system, an RTGS at the central bank, and the connection of major commercial banks to the RTGS. This requirement is especially important in case of a decentralized TSA architecture. The treasury could also be connected to the RTGS.

- $\quad$ Appropriate interface between the treasury and the banking network. The interface between the treasury, line agencies and the banking network should be agreed by all the stakeholders and formalized through agreements. Such agreements should provide for the modalities of issuing payment orders/checks, and the the arrangements for reporting and reconciliation. An electronic interface between the treasury and the banking network through an IFMIS would facilitate a full-scale centralized TSA. This should be addressed during the conceptual design phase of the TSA and the IFMIS.

- A comprehensive chart of accounts. With the establishment of a TSA, some information that is currently available from the banking system is likely to be lost. If such data are relevant for budget management purposes, they should be captured through the chart of accounts, which may require modification. This work should also be completed during the conceptual design phase of the TSA and the IFMIS.

- $\quad$ Capacity development of the TSA users. The prospective users of the TSA system both within the MoF/treasury and line agencies will need to be trained in the new procedures and applications. Such training should be carefully coordinated with the introduction of the TSA. A user manual on receipt and payment procedures under the TSA system should also be developed. 


\section{Implementation Issues}

\section{Based on the above, the implementation of a TSA should include the following key steps:}

- $\quad$ The MoF/treasury should prepare a comprehensive plan for implementing the TSA, covering all key functional and technical requirements, identifying any required amendments to the existing laws and regulations, and specifying the revised receipt and payment procedures.

- $\quad$ Revised templates should be developed for reporting by the banks on government transactions under the TSA. Key elements of the daily reports from the banks should include daily opening and closing balances, and a summary of receipt and payment transactions on a daily basis. An appropriate format for monthly aggregate reports should also be developed.

- $\quad$ An orderly migration of cash balances from the commercial bank accounts to the TSA should be implemented, with a view to ensuring minimal disruption to banking system liquidity and monetary policy.

- A decision on the timing of the introduction of the new arrangements should be taken: for accounting purposes, it may be preferable to coincide changes in banking arrangements with the beginning of the fiscal year.

- When commercial banks are involved in revenue collection or expenditure payments, the banking arrangements, including the remuneration of commercial banks for providing transaction banking services to the Treasury, must be negotiated competitively and contracted by the MoF/treasury. ${ }^{33}$ The relationship between the government's primary banker (normally the central bank) and other commercial banks must be clearly defined.

- $\quad$ The MoF/treasury should work closely with the ministries and budget institutions, to ensure that the latter have full information about the reforms and the necessary changes in their banking and payment arrangements.

In many cases, a full TSA would require a staged implementation. Transitional arrangements for moving from existing accounting and banking systems to the TSA should be decided. During this period, the MoF/treasury and the central bank should closely monitor the implementation of the new arrangements on a daily basis, and establish procedures for

${ }^{33}$ A start should be made by establishing businesslike arrangements between the government and the banking system. The principle that the government should earn interest on all its deposits and that it should, in turn, pay for all the banking services it receives should be seriously explored. Moreover, bank remuneration through fees instead of allowing banks to benefit through floats is more transparent and promotes competitive bidding. 
resolving procedural difficulties. The objective should be a progressive integration of government bank accounts operated by the treasury and by budget institutions into the TSA without disruption to the ongoing financial operations of the treasury. The use of pilot projects in selected ministries/agencies could be considered. Drawing on the experience of these pilots, the TSA could be rolled out to all line ministries/agencies. While it might be necessary to keep a certain number of cash holding accounts in the commercial banks initially, this number should be further rationalized in the medium to long term.

\section{Conclusions}

Many developing and low-income countries have fragmented government banking arrangements that hinder effective cash management and control over cash balances. It is common to find multiple bank accounts in commercial banks belonging to different ministries/agencies, with idle cash sitting there.

The primary objective of a TSA is to ensure effective aggregate control over government cash balances. The consolidation of cash resources through a TSA arrangement is meant to optimize government cash management. It avoids borrowing and paying additional interest charges to finance the expenditures of some agencies while other agencies keep idle balances in their bank accounts. Effective aggregate control of cash is also a key element in monetary and budget management. Other objectives of a TSA include: reliable and efficient budget execution by minimizing transaction costs; monitoring (and thereby controlling the delay in) the remittance of government revenues (both tax and nontax) by the collecting banks; effective reconciliation between banking and accounting data; efficient control and monitoring of funds allocated to various government agencies; and facilitating better coordination with the monetary policy implementation.

Any TSA has at least two central attributes: (i) it is a unified arrangement, which enhances the fungibility of the government's cash resources, and implies that no other government agency should be allowed to operate bank accounts without the oversight of the treasury; and (ii) it is comprehensive, encompassing all government cash, both budgetary and extrabudgetary.

Regarding the "architecture" of the TSA, it should be underscored that there is no single TSA model or design. The TSA model to be implemented in each country depends on the stage of development of the quality of its public institutions and financial management systems, its technological development and communications infrastructure, and the degree of maturity of its banking system.

In countries with well developed PFM systems, adequate technological infrastructure and sophisticated banking systems, best practice implies creating a TSA in the central bank, 
while the treasury uses a well developed treasury general ledger (TGL) to record all the transactions of different entities. The spending agencies could have transaction accounts in commercial banks, but these should be established on a zero-balance basis.

The design of a TSA also depends on the technology used for interbank settlements and the system, electronic and/or manual, used by the central bank for clearing of collections and payments with the commercial banks. In some cases, the banking system might also be moving to a Real Time Gross Settlements System (RTGS). To make the operation of the TSA more efficient, procedures for transferring revenues to the TSA should be streamlined through the banking system; and procedures for transferring funds to the bank accounts of suppliers and other beneficiaries, should similarly be enhanced through an electronic fund transfer system (EFT).

The decision on whether — and to what extent— budget authority should be delegated to ministries and spending units is independent of the TSA structure. In many developed countries with highly decentralized budget and accounting systems, spending agencies have considerable autonomy in implementing the budget. The TSA enhances the transparency of the government's banking arrangements by ensuring that all end-of-the-day balances are electronically swept into the TSA.

Issues related to cash management should not be confused with issues related to the distribution of responsibilities for accounting control and administration of the payment system. A TSA can operate with both centralized and decentralized (or deconcentrated) transaction processing and accounting control systems. However, the feasibility of its implementation depends on the level of technological development of the banking sector and the government's banking arangements, including a reliable communications network.

To sum up, the establishment of a TSA is a key element of an efficient and effective public financial management system and an essential tool for minimizing government borrowing costs. Regardless of their degree of development, all countries should aim at establishing a TSA provided this takes into account the preconditions identified in this paper, and is introduced in a way that fully reflects countries' unique circumstances. 
APPENDIX I. TSA COUNTRY EXAMPLES ${ }^{1}$

\begin{tabular}{|c|c|c|c|c|c|}
\hline \multicolumn{6}{|c|}{ OECD COUNTRIES } \\
\hline Country & Description & Coverage & $\begin{array}{c}\text { Degree of } \\
\text { Centralization }\end{array}$ & $\begin{array}{c}\text { Role of } \\
\text { Commercial } \\
\text { Banks }\end{array}$ & $\begin{array}{c}\text { Availability } \\
\text { of IFMIS }\end{array}$ \\
\hline France & $\begin{array}{l}\text { France has a well developed TSA at the central bank (Banque de } \\
\text { France). The TSA includes the balances of local authorities, } \\
\text { municipalities, and quasi-governmental bodies as well as of central } \\
\text { government revenue and spending departments (including overseas } \\
\text { authorities). Social security funds are managed by public accountants } \\
\text { (under the Direction Generale des Finances Publiques, DGFIP), but not } \\
\text { by the treasury. They are not held in the TSA, but in a state-owned } \\
\text { savings bank. Cash (and debt) management is the responsibility of } \\
\text { Agence France Trésor (AFT), which is an agency of the French Treasury, } \\
\text { which in turn is part of the Ministry of Economy, Finance and Industry. } \\
\text { AFT actively manages the TSA, and has developed a cash flow } \\
\text { forecasting capability accordingly. It invests (and if necessary borrows) } \\
\text { surplus funds in the money markets, with a view to maintaining a low and } \\
\text { stable end of day balance in the TSA and ensuring the best return on the } \\
\text { investment of surplus cash. AFT operates a centralized payment system. } \\
\text { The spending agencies make expenditure commitments and forward } \\
\text { payment requests to one of the nearly } 4500 \text { regional treasuries. } \\
\text { Payments are made from the regional sub-accounts of the TSA. Closing } \\
\text { balances in the sub-accounts are swept into the TSA in real time. The } \\
\text { government does not use accounts with commercial banks. } \\
\text { Historically, the coverage of the French Treasury (Trésor) has been very } \\
\text { broad compared to treasuries in other OECD countries. It extended } \\
\text { beyond the general government and covered other public entities } \\
\text { including state-owned enterprises (SOEs). The Trésor also received } \\
\text { deposits from the public. Government cash management in France refers } \\
\text { to the management by the AFT of all cash flows that are brought to } \\
\text { account in the TSA at the Banque de France. All central government } \\
\text { cash flows (including investment flows) and financing transactions are } \\
\text { included, with only very marginal exceptions. }{ }^{2} \text { It also includes the cash } \\
\text { flows of "treasury correspondents"; these are the regional and local } \\
\text { governments, public establishments and businesses which, by virtue of } \\
\text { legislative obligations or convenience, keep an account within the TSA. } \\
\text { While movements in the accounts of treasury correspondents do not }\end{array}$ & $\begin{array}{l}\text { National and } \\
\text { regional/local } \\
\text { governments } \\
\text { and quasi- } \\
\text { governmental } \\
\text { bodies. } \\
\text { Social Security } \\
\text { Fund is } \\
\text { managed by the } \\
\text { treasury, but } \\
\text { held in a state- } \\
\text { owned savings } \\
\text { bank }\end{array}$ & $\begin{array}{l}\text { Fully } \\
\text { centralized } \\
\text { architecture, } \\
\text { with regional } \\
\text { sub-accounts } \\
\text { of the TSA }\end{array}$ & No involvement & $\begin{array}{l}\text { IFMIS, } \\
\text { including an } \\
\text { interface with } \\
\text { the central } \\
\text { bank for TSA } \\
\text { operation }\end{array}$ \\
\hline
\end{tabular}




\begin{tabular}{|c|c|c|c|c|c|}
\hline & $\begin{array}{l}\text { directly concern the central government from a control perspective, they } \\
\text { do have a direct impact on the TSA, and therefore they affect the AFT's } \\
\text { cash management task. } \\
\text { Under recent reforms, however, the coverage of the TSA has been } \\
\text { steadily shrinking. During 2002, the "Trésor public" stopped receiving } \\
\text { deposits from the public, and removed the SOEs and Postal department } \\
\text { from its purview. Apart from the main government flows, currently only } \\
\text { major extra-budgetary funds like social security are managed by the } \\
\text { Trésor. Social security funds are not held in the TSA, but in the Caisse } \\
\text { des Depots et Consignations, a state-owned savings bank. However, the } \\
\text { scope of the TSA remains very broad and avoiding its shrinking is part of } \\
\text { the structural commitment to optimize government debt. }\end{array}$ & & & & \\
\hline $\begin{array}{l}\text { United } \\
\text { Kingdom }\end{array}$ & $\begin{array}{l}\text { All central government cash balances are aggregated into a TSA } \\
\text { maintained at the central bank. There are no extra-budgetary funds that } \\
\text { are outside the system. Local authorities and SOEs are outside the } \\
\text { central system and hold their cash balances in the commercial banking } \\
\text { system. The two main central government funds are the Consolidated } \\
\text { Fund (CF) and the National Loans Fund (NLF). If the CF has a surplus, } \\
\text { this is automatically transferred to the NLF to reduce its need to borrow, } \\
\text { and vice versa. The NLF formally borrows money for the government and } \\
\text { funds lending to local authorities. The Debt Management Account (DMA), } \\
\text { which is managed by the U.K. Debt Management Office (DMO), is used } \\
\text { to balance any daily surplus or deficit in the NLF. The CF receives the } \\
\text { proceeds of general taxation and other receipts. It pays out to spending } \\
\text { departments and agencies the sums needed to meet commitments. } \\
\text { Departments' bank accounts are managed by the Government Banking } \\
\text { Service (GBS). The GBS replaced the former Office of the Paymaster } \\
\text { General on April 1, 2008, although its functions are broadly similar. Most } \\
\text { of the functions of the GBS are, however, contracted out to a "service } \\
\text { integrator." This agency in turn contracts out cash handling and } \\
\text { transaction banking services to one of the commercial banks, and the } \\
\text { balances in the respective transaction accounts are swept overnight into } \\
\text { the TSA. GBS also directly manages some contracts with banks on } \\
\text { behalf of some of the largest government users of the banking system. } \\
\text { GBS has a single main account at the Bank of England and provides } \\
\text { payments facilities for most central government departments and related } \\
\text { bodies. Once the provision to meet spending commitments is transferred } \\
\text { from the CF to the respective GBS sub-account, it is under control of the } \\
\text { respective spending unit, and that unit controls all disbursements. For the } \\
\text { most part, GBS accounts are temporary resting places for money drawn } \\
\text { from or coming to the CF. It is expenditure out of the GBS accounts or }\end{array}$ & $\begin{array}{l}\text { National } \\
\text { government }\end{array}$ & $\begin{array}{l}\text { Fully } \\
\text { centralized } \\
\text { architecture }\end{array}$ & $\begin{array}{l}\text { Yes, significant } \\
\text { involvement }\end{array}$ & Yes \\
\hline
\end{tabular}




\begin{tabular}{|c|c|c|c|c|c|}
\hline & $\begin{array}{l}\text { receipts into them that score as government expenditure and revenue. } \\
\text { Transfers between the GBS and Consolidated Fund, and between the } \\
\text { Consolidated Fund, NLF, and DMA, are internal to government. The } \\
\text { linkage between the government accounts (known as the "Exchequer } \\
\text { Pyramid") means that all balances held at the Bank of England are swept } \\
\text { into a single account, i.e., the DMA, the DMO's account, at the end of the } \\
\text { business day. In this way the net surplus or deficit on all the lower } \\
\text { accounts passes to the DMA. All the accounts below the DMA have zero } \\
\text { balances overnight. }\end{array}$ & & & & \\
\hline Australia & $\begin{array}{l}\text { The Department of Finance and Administration (DFA) is responsible for } \\
\text { banking and payment arrangements within government. The DFA holds } \\
\text { the main government bank accounts at the central bank, the Reserve } \\
\text { Bank of Australia (RBA). The main account at the RBA is the Official } \\
\text { Public Account (OPA). This account provides funding for all spending } \\
\text { accounts of departments. Funding is provided to the departments one } \\
\text { day in advance based on the cash flow projections of expenditure } \\
\text { received from the departments. Balances of departmental and agency } \\
\text { expenditure accounts are swept overnight into the OPA, but are returned } \\
\text { the next day. There is also an Official Consolidated Receipts account } \\
\text { where all government receipts from departmental receipt accounts are } \\
\text { consolidated overnight. Departmental payments are to some extent } \\
\text { executed through the commercial banking system. Under the devolved } \\
\text { banking arrangements all departments are required to contract banking } \\
\text { services, and they can choose to do this with commercial banks or rely } \\
\text { on the RBA. }\end{array}$ & $\begin{array}{l}\text { National } \\
\text { government }\end{array}$ & $\begin{array}{l}\text { A mixed } \\
\text { architecture } \\
\text { (with elements } \\
\text { of both } \\
\text { centralized } \\
\text { and } \\
\text { decentralized } \\
\text { models of } \\
\text { TSA) }\end{array}$ & $\begin{array}{l}\text { The central } \\
\text { Bank is the } \\
\text { manager of the } \\
\text { TSA, but } \\
\text { departmental } \\
\text { payments are } \\
\text { executed } \\
\text { through the } \\
\text { commercial } \\
\text { banking system. }\end{array}$ & Yes \\
\hline $\begin{array}{l}\text { United } \\
\text { States }\end{array}$ & $\begin{array}{l}\text { The U.S. Treasury maintains a consolidated funds pool, in a single } \\
\text { account, for all funds of the federal government. The Federal Reserve } \\
\text { Banks (FRBs) act as the main government banks. As such, the FRBs, } \\
\text { and specifically the Federal Reserve Bank of New York (FRBNY), } \\
\text { maintain the treasury's general account (TGA), accept deposits of federal } \\
\text { taxes and other federal agency receipts, and process checks and } \\
\text { electronic payments drawn on the TGA. The treasury holds all funds, with } \\
\text { very few exceptions, under the management of its fiscal agent, the } \\
\text { FRBNY. Actual disbursements are administered through the } \\
\text { intermediation of the FRBs and are reflected in the TGA in real time. } \\
\text { While all treasury disbursements are made from the TGA, a network of } \\
\text { several thousand financial institutions collects the major part of all tax } \\
\text { revenues. Under the single account system, each agency and bureau is } \\
\text { given accounting control and responsibility for the timing and use of its } \\
\text { funds. However, the agency/bureau does not actually hold those funds in } \\
\text { separate bank accounts outside the treasury. The treasury operations } \\
\text { cover a complete range of public funds at the federal level, including } \\
\text { budget funds, trust funds, revolving funds, and other funds. State and }\end{array}$ & $\begin{array}{l}\text { Federal } \\
\text { government }\end{array}$ & $\begin{array}{l}\text { Decentralized } \\
\text { architecture, } \\
\text { with FRBs } \\
\text { acting as the } \\
\text { main } \\
\text { government } \\
\text { banks for } \\
\text { agencies, who } \\
\text { are given } \\
\text { responsibility } \\
\text { for accounting } \\
\text { control and } \\
\text { use of funds }\end{array}$ & $\begin{array}{l}\text { Some } \\
\text { involvement, } \\
\text { with Central } \\
\text { Bank being the } \\
\text { manager of TSA }\end{array}$ & Yes \\
\hline
\end{tabular}




\begin{tabular}{|c|c|c|c|c|c|}
\hline & $\begin{array}{l}\text { local governments have full independence in managing their own funds } \\
\text { and they make use of depository institutions outside the central bank } \\
\text { system. }\end{array}$ & & & & \\
\hline Sweden & $\begin{array}{l}\text { There are around } 270 \text { central government "authorities" in Sweden. They } \\
\text { make, or receive, a large number of payments. Authority payments } \\
\text { (including the Swedish Social Insurance Administration) are collected in a } \\
\text { central account (SCR) that the Debt Office (DO) has at the central bank } \\
\text { (Riksbank). Cash flows are netted there and, depending on whether there } \\
\text { is a surplus or deficit in the account, deposits are made or funds are } \\
\text { provided centrally by the DO in order to make the final balance zero } \\
\text { every day. Every authority has one or more transaction accounts at one } \\
\text { or more banks. The balances in the authorities' transaction accounts are } \\
\text { transferred to and collected in a top account at the respective bank and } \\
\text { then onward to the SCR. This takes place three times a day. The } \\
\text { authorities' accounts at the DO are interest-bearing. The DO procures } \\
\text { payment services by framework agreements with the banks. The } \\
\text { agreements regulate various types of payment services that the } \\
\text { authorities can use. They can choose the bank they wish to use to make } \\
\text { payments. The authorities sign sub-agreements with the banks based on } \\
\text { the framework agreement. Each public authority must pay for the banking } \\
\text { services it uses. A ranking system is used so that the authorities can } \\
\text { "cherry pick" banks to provide specific services. The DO finances its } \\
\text { temporary cash needs by borrowing on the interbank market. }\end{array}$ & $\begin{array}{l}\text { Central/national } \\
\text { government }\end{array}$ & $\begin{array}{l}\text { Decentralized } \\
\text { architecture. } \\
\text { Central } \\
\text { government } \\
\text { agencies sign } \\
\text { agreements } \\
\text { with banks and } \\
\text { pay for the } \\
\text { banking } \\
\text { services used } \\
\text { by them }\end{array}$ & $\begin{array}{l}\text { Commercial } \\
\text { banks provide } \\
\text { transaction } \\
\text { banking } \\
\text { services. } \\
\text { Central } \\
\text { government } \\
\text { agencies have } \\
\text { transaction } \\
\text { accounts at one } \\
\text { or more } \\
\text { commercial } \\
\text { banks }\end{array}$ & Yes \\
\hline $\begin{array}{l}\text { New } \\
\text { Zealand }\end{array}$ & $\begin{array}{l}\text { The government holds its main bank account at the central bank, the } \\
\text { Reserve Bank of New Zealand (RBNZ). This account, known as the } \\
\text { Crown Settlement Account (CSA), effectively operates as a TSA. All } \\
\text { wholesale financial markets flows between government departments and } \\
\text { the private sector, as well as between government departments and the } \\
\text { RBNZ, pass through this account directly. All retail flows between } \\
\text { government departments and the private sector are transacted through a } \\
\text { commercial bank, the net value of which are swept daily between the } \\
\text { commercial bank and the CSA. Transactions for government entities } \\
\text { other than departments (e.g., Crown entities, state-owned enterprises) } \\
\text { are transacted outside of the CSA. The RBNZ provides settlement } \\
\text { accounts for banks which are used to settle interbank clearings. To } \\
\text { facilitate the exchange settlement account service, the RBNZ operates a } \\
\text { system which provides real-time, final, irrevocable payments between } \\
\text { account holders. Transactions by government departments create cash } \\
\text { flows between the CSA and the other settlement accounts maintained by } \\
\text { the commercial banks. }\end{array}$ & National & $\begin{array}{l}\text { Fully } \\
\text { centralized } \\
\text { architecture }\end{array}$ & $\begin{array}{l}\text { Commercial } \\
\text { banks provide } \\
\text { retail/transaction } \\
\text { banking } \\
\text { services }\end{array}$ & Yes \\
\hline
\end{tabular}




\begin{tabular}{|c|c|c|c|c|c|}
\hline \multicolumn{6}{|c|}{ LATIN AMERICAN CountRIES } \\
\hline Country & Description & Coverage & $\begin{array}{c}\text { Degree of } \\
\text { Centralization }\end{array}$ & $\begin{array}{c}\text { Role of } \\
\text { Commercial } \\
\text { Banks }\end{array}$ & $\begin{array}{l}\text { Availability } \\
\text { of IFMIS }\end{array}$ \\
\hline Brazil & $\begin{array}{l}\text { The TSA is located at the central bank (BACEN) and its management is } \\
\text { assigned to the National Treasury Secretariat (STN) of the MoF which } \\
\text { also has to prepare the cash plan, administer the public debt, produce } \\
\text { the federal accounts and manage the financial administration information } \\
\text { system (SIAFI). The TSA covers only the federal government entities } \\
\text { (each state has its own TSA). It also includes the transactions of the } \\
\text { Social Security fund (INSS), and special accounts in foreign currencies } \\
\text { (including external loans). The collection of revenues and payments } \\
\text { transactions are handled through the largest public commercial bank } \\
\text { (Banco de Brasil, BB), and only in some exceptional cases other } \\
\text { commercial banks authorized by the STN are used. Given that the SIAFI } \\
\text { technology is not web-based, some revenue and payment transactions } \\
\text { and account reconciliations are not performed automatically. The } \\
\text { revenues collected are transferred to the TSA the same day that they are } \\
\text { received by the BB. To process payments, electronic documents called } \\
\text { "banking orders" (whose characteristics vary according to the type of } \\
\text { payment) are prepared by the public entities. These orders are } \\
\text { consolidated in magnetic files and submitted to any of the BB offices } \\
\text { around the country (not transmitted electronically). The BB sends them to } \\
\text { the STN, and the latter authorizes BACEN to transfer to the BB the } \\
\text { resources needed to make the payments. The balances maintained with } \\
\text { the BB are remunerated at the average rate of the bond portfolio of } \\
\text { BACEN. In 2002, a National Payments System (SPB) was introduced, } \\
\text { which includes a large-value RTGS system operated by BACEN. } \\
\text { Commercial banks play a central role in collecting and paying on behalf } \\
\text { of the three levels of government. SPB has enabled monitoring of the } \\
\text { BACEN accounts in real time, shortened tax collection lags, and allowed } \\
\text { for faster payments to beneficiaries at less cost. The extensive use of } \\
\text { earmarking makes the transfer of excess cash in some accounts to pay } \\
\text { for expenditures not related to earmarked programs a cumbersome } \\
\text { process, limiting the flexibility of budget execution. }\end{array}$ & $\begin{array}{l}\text { National } \\
\text { government }\end{array}$ & $\begin{array}{l}\text { Fully } \\
\text { centralized } \\
\text { architecture }\end{array}$ & $\begin{array}{l}\text { Some } \\
\text { involvement. In } \\
\text { particular, } \\
\text { commercial } \\
\text { banks play a } \\
\text { central role in } \\
\text { collecting and } \\
\text { paying on } \\
\text { behalf of the } \\
\text { government }\end{array}$ & $\begin{array}{l}\text { IFMIS, } \\
\text { including an } \\
\text { interface with } \\
\text { the Bank for } \\
\text { TSA operation }\end{array}$ \\
\hline Perú & $\begin{array}{l}\text { The TSA is located in, and managed by, the main public commercial } \\
\text { bank (Banco de la Nación, BN). Thousands of public accounts exist at } \\
\text { the BN. The own-source revenues of the central government entities are } \\
\text { not included in the TSA. The bank charges for its services through a fee } \\
\text { not related to the number of transactions. The BN is the only provider of }\end{array}$ & $\begin{array}{l}\text { National } \\
\text { government }\end{array}$ & $\begin{array}{l}\text { A mix of both } \\
\text { centralized } \\
\text { and } \\
\text { decentralized } \\
\text { architectures }\end{array}$ & $\begin{array}{l}\text { Full } \\
\text { involvement, } \\
\text { with TSA being } \\
\text { managed by the } \\
\text { main public }\end{array}$ & $\begin{array}{l}\text { IFMIS without } \\
\text { an interface }\end{array}$ \\
\hline
\end{tabular}




\begin{tabular}{|c|c|c|c|c|c|}
\hline & $\begin{array}{l}\text { revenue collection and payment services. Taxes, fines and fees may be } \\
\text { paid at any bank and many government offices in the country, but all } \\
\text { must be wire transferred the next day into the BN's main account (a } \\
\text { collections holding account). The balances in most accounts are swept at } \\
\text { the end of the day and transferred to the central bank (BCRP) to be } \\
\text { invested overnight or at longer terms. The treasury has no control on how } \\
\text { these resources are invested. It only informs the BCRP on a daily basis } \\
\text { how much of the collections are to be deposited overnight, and gives } \\
\text { disbursement instructions for payments to be made the following day. } \\
\text { BCRP manages the short-term investment of the cash balances. } \\
\text { Resources earmarked to the municipalities, such as those from royalties, } \\
\text { canon (revenue or production sharing from the oil, gas and mining } \\
\text { sectors mainly) and participaciones (municipalities' share of custom } \\
\text { revenues and from a tax on gambling activities), pass through the TSA } \\
\text { before being allocated to them. An estimated } 80 \% \text { of the total budget of } \\
\text { the subnational governments was allocated through the TSA in } 2009 \text {. }\end{array}$ & & & $\begin{array}{l}\text { commercial } \\
\text { bank (a } \\
\text { specialized } \\
\text { bank) }\end{array}$ & \\
\hline Colombia & $\begin{array}{l}\text { Although a TSA nominally exists, the treasury currently manages more } \\
\text { than } 200 \text { accounts in the central bank (Banco de la República, BR), } \\
\text { instead of using the treasury general ledger incorporated in the IFMIS to } \\
\text { identify agency-specific transactions. The treasury also has a number of } \\
\text { accounts in commercial banks (Banco Agrario, Banco Popular, Banco } \\
\text { Ganadero, Banco de Occidente) and these appear to serve specialized } \\
\text { purposes. The "TSA" does not include the own source revenues of the } \\
\text { "decentralized institutions" (called "public establishments"), all resources } \\
\text { of some key autonomous public establishments (such as the ICBF and } \\
\text { SENA), or the Social Security Institute. Some } 150 \text { agencies have own } \\
\text { source revenues. To expand coverage, the authorities took the step of } \\
\text { instructing all these entities to invest their surplus cash in treasury bills. } \\
\text { This is done through a cumbersome process. Collection of revenues and } \\
\text { payment disbursements are done through a number of commercial } \\
\text { banks. These banks are remunerated for their services by allowing them } \\
\text { to retain the public funds deposited with them for } 14 \text { days. The BR } \\
\text { manages the treasury's liquidity. Each day, the Treasury notifies the BR } \\
\text { of its cash needs for the following day. The BR manages all investment } \\
\text { operations and the deposits (invested in financial instruments between } 1 \\
\text { and } 90 \text { days) are remunerated at a reference rate. The difficulties posed } \\
\text { by the implementation of a modern financial information system (SIIF II) } \\
\text { are still to be overcome. }\end{array}$ & $\begin{array}{l}\text { National } \\
\text { government, but } \\
\text { does not } \\
\text { include the } \\
\text { public } \\
\text { establishments }\end{array}$ & $\begin{array}{l}\text { Fully } \\
\text { centralized } \\
\text { architecture }\end{array}$ & $\begin{array}{l}\text { The central } \\
\text { bank is the } \\
\text { manager of the } \\
\text { TSA, but the } \\
\text { revenue } \\
\text { collection and } \\
\text { payment } \\
\text { disbursements } \\
\text { are done } \\
\text { through a } \\
\text { number of } \\
\text { commercial } \\
\text { banks }\end{array}$ & $\begin{array}{l}\text { IFMIS is yet to } \\
\text { stabilize and } \\
\text { does not have } \\
\text { an interface } \\
\text { with the TSA } \\
\text { bank }\end{array}$ \\
\hline
\end{tabular}




\section{Eastern Europe and Central Asian (ECA) Countries}

\begin{tabular}{|c|c|c|c|c|c|}
\hline Country & Description & Coverage & $\begin{array}{c}\text { Degree of } \\
\text { Centralization }\end{array}$ & $\begin{array}{l}\text { Role of } \\
\text { Commercial } \\
\text { Banks }\end{array}$ & $\begin{array}{c}\text { Availability } \\
\text { of IFMIS }\end{array}$ \\
\hline $\begin{array}{l}\text { Russian } \\
\text { Federation }\end{array}$ & $\begin{array}{l}\text { The TSA is located at the central bank (CBRF). There are "collection } \\
\text { accounts" maintained by the regional treasury offices (RTOs) with the } \\
\text { CBRF for the collection of taxes, duties, etc.; an "operational account" is } \\
\text { maintained by the RTOs for spending federal budget funds; and } \\
\text { separate accounts exist for recording expenditures financed from } \\
\text { specialized sources, and for foreign currency, among others. All federal } \\
\text { budget revenues and expenditures pass through the TSA. The federal } \\
\text { budget is executed via the bank accounts maintained by the relevant } \\
\text { RTOs. All federal budget revenues and expenditures are posted to the } \\
\text { treasury general ledger (TGL) on a daily basis. The CBRF transfers } \\
\text { funds from the TSA to the RTOs operational accounts (within the } \\
\text { available balances at the TSA) as per the RTO's request. The RTOs } \\
\text { make payments to beneficiaries through the operational accounts on } \\
\text { behalf of the spending units (SUs). The local treasury offices record and } \\
\text { submit information on executed expenditures to the SUs concerned. If so } \\
\text { required, the RTOs transfer funds from the operational account to the } \\
\text { "cash disbursement" accounts opened for the federal treasury offices } \\
\text { and the SUs withdraw cash from these accounts. }\end{array}$ & $\begin{array}{l}\text { National } \\
\text { government }\end{array}$ & $\begin{array}{l}\text { Fully } \\
\text { centralized } \\
\text { architecture, } \\
\text { with regional } \\
\text { treasury } \\
\text { offices }\end{array}$ & $\begin{array}{l}\text { Almost no } \\
\text { involvement }\end{array}$ & Yes \\
\hline $\begin{array}{l}\text { Kyrgyz } \\
\text { Republic }\end{array}$ & $\begin{array}{l}\text { The TSA has a wide coverage, including subnational government } \\
\text { resources. It is maintained at the central bank. Cash disbursement } \\
\text { accounts are opened with the central bank/agent banks located closest } \\
\text { to the regional treasury offices (RTOs). These RTOs are empowered to } \\
\text { approve cash checks. The treasury may open additional accounts in the } \\
\text { central bank to handle payments and receipts (such as foreign currency } \\
\text { accounts). Disbursements are made based on the spending units' } \\
\text { requests delivered to the treasury from the RTOs. Funds are transferred } \\
\text { to the beneficiaries' accounts. If so required, cash disbursements may } \\
\text { be made using two schemes: (i) a settlement compensation } \\
\text { arrangement between the agent banks (maintaining the cash } \\
\text { disbursement accounts) and the central bank; and (ii) if there are } \\
\text { insufficient bank resources, transfers of funds by the central bank from } \\
\text { the TSA to the regional treasury offices' agent bank account, with a lag } \\
\text { of one day. }\end{array}$ & $\begin{array}{l}\text { National and } \\
\text { subnational } \\
\text { governments }\end{array}$ & $\begin{array}{l}\text { A mix of both } \\
\text { centralized } \\
\text { and } \\
\text { decentralized } \\
\text { architectures }\end{array}$ & $\begin{array}{l}\text { Some } \\
\text { involvement, } \\
\text { with cash } \\
\text { disbursement } \\
\text { accounts } \\
\text { opened with } \\
\text { agent } \\
\text { commercial } \\
\text { banks }\end{array}$ & $\begin{array}{l}\text { The IFMIS is } \\
\text { under } \\
\text { development }\end{array}$ \\
\hline Georgia & $\begin{array}{l}\text { The TSA is held at the central bank. It includes the Social Insurance } \\
\text { State Fund and other funds. For processing payments, the regional } \\
\text { treasury offices that serve the spending units enter the data on the }\end{array}$ & $\begin{array}{l}\text { National } \\
\text { government and } \\
\text { social security }\end{array}$ & $\begin{array}{l}\text { Fully } \\
\text { centralized } \\
\text { architecture, }\end{array}$ & $\begin{array}{l}\text { Some } \\
\text { involvement } \\
\text { (particularly for }\end{array}$ & Yes \\
\hline
\end{tabular}




\begin{tabular}{|c|c|c|c|c|c|}
\hline & $\begin{array}{l}\text { payment request received from each spending unit in the information } \\
\text { system and send electronic payment requests in batches to the } \\
\text { settlement center of the central treasury. The information system } \\
\text { generates payment orders (POs) and the settlement center sends them } \\
\text { to the central bank electronically in batches. The central bank executes } \\
\text { the POs through the RTGS and transfers funds to the accounts of } \\
\text { suppliers and beneficiaries with commercial banks. The information } \\
\text { system generates the relevant accounting entries in the TGL. Revenues } \\
\text { are collected through commercial bank branches, which in turn are } \\
\text { supposed to transfer the funds the same day to the TSA. }\end{array}$ & funds & $\begin{array}{l}\text { with a network } \\
\text { of regional } \\
\text { treasury } \\
\text { offices }\end{array}$ & $\begin{array}{l}\text { revenue } \\
\text { collection), with } \\
\text { the central bank } \\
\text { managing the } \\
\text { TSA }\end{array}$ & \\
\hline Moldova & $\begin{array}{l}\text { The treasury has three main accounts at the central bank (National Bank } \\
\text { of Moldova, NBM): the state budget (SB), the Social Security Agency } \\
\text { (SSA), and the Health Insurance Agency (HIA). Each territorial treasury } \\
\text { office (TTO) has three local bank accounts: a state budget account (SB } \\
\text { ZBA), a Special Means and Funds (SMF) Account, and a local budget } \\
\text { account. All tax revenues and revenues of the SSA and HIA are } \\
\text { collected through commercial bank branches, and are supposed to be } \\
\text { transferred to the TSA on a daily basis. All SMF revenues are collected } \\
\text { in the respective TTOs' bank accounts. When a budget unit wants to } \\
\text { make a payment, it submits a payment order (PO) to the respective } \\
\text { TTO, which processes and records the request and submits it to the } \\
\text { treasury. The latter sends the PO to the NBM, which transfers funds } \\
\text { from the SB account in the TSA to the SB ZBA through the Interbank } \\
\text { system for automatic payments. For cash payments, TTOs give a check } \\
\text { to the budget unit, which is then presented to the respective commercial } \\
\text { bank. For non-cash payments, TTOs send POs to their local commercial } \\
\text { bank branches, which forward them to their head offices to be cleared } \\
\text { and settled with the TSA. After the payment is made, the commercial } \\
\text { bank branches send account statements to the TTOs, which process } \\
\text { them and submit data to the treasury. Daily reconciliation takes place } \\
\text { between the NBM and treasury for payments and receipts. }\end{array}$ & $\begin{array}{l}\text { National } \\
\text { government and } \\
\text { social security } \\
\text { funds }\end{array}$ & $\begin{array}{l}\text { A mix of both } \\
\text { centralized } \\
\text { and } \\
\text { decentralized } \\
\text { architectures }\end{array}$ & $\begin{array}{l}\text { Some } \\
\text { involvement, } \\
\text { with commercial } \\
\text { banks providing } \\
\text { revenue } \\
\text { collection and } \\
\text { payment } \\
\text { services }\end{array}$ & Yes \\
\hline Tajikistan & $\begin{array}{l}\text { The TSA is yet to be established. All tax revenues are collected through } \\
\text { transit accounts in commercial banks, who then transfer the respective } \\
\text { share of the republican and local governments to the local bank } \\
\text { accounts of treasury offices (TO) with the Amonat Bank (AB, a state- } \\
\text { owned commercial bank) with several days of delay. TOs provide } \\
\text { information on local revenues by phone weekly and by monthly reports. } \\
\text { The extent of idle balances in the local bank accounts of TOs is not } \\
\text { known. For expenditure payments, budget organizations send payment } \\
\text { orders (POs) to the regional TOs, which then process the POs manually } \\
\text { and (if found in order) authorize and submit them to a local branch of the } \\
\text { AB for payment to the supplier/beneficiary's bank account. TOs submit } \\
\text { monthly expenditure reports on their budgets to the central treasury by }\end{array}$ & $\begin{array}{l}\text { National } \\
\text { government }\end{array}$ & $\begin{array}{l}\text { Fully } \\
\text { centralized } \\
\text { architecture, } \\
\text { with regional } \\
\text { treasury } \\
\text { offices }\end{array}$ & $\begin{array}{l}\text { Revenue } \\
\text { collection and } \\
\text { payment } \\
\text { disbursements } \\
\text { are mainly } \\
\text { conducted } \\
\text { through a state- } \\
\text { owned } \\
\text { commercial } \\
\text { bank }\end{array}$ & No IFMIS \\
\hline
\end{tabular}




\begin{tabular}{|c|c|c|c|c|c|}
\hline & $\begin{array}{l}\text { courier or post. The Social Protection Fund (SPF) has separate accounts } \\
\text { at the AB. The SPF makes payments through its separate bank } \\
\text { accounts in the AB at the central and local levels and sends monthly } \\
\text { reports on payments to the treasury by courier or post. }\end{array}$ & & & & \\
\hline \multicolumn{6}{|c|}{ SOME ASIAN COUNTRIES } \\
\hline Country & Description & Coverage & $\begin{array}{c}\text { Degree of } \\
\text { Centralization }\end{array}$ & $\begin{array}{l}\text { Role of } \\
\text { Commercial } \\
\text { Banks }\end{array}$ & $\begin{array}{c}\text { Availability } \\
\text { of IFMIS }\end{array}$ \\
\hline India & $\begin{array}{l}\text { India has TSAs established both at the federal and state government } \\
\text { levels. Under an agreement entered into by the federal government with } \\
\text { the Reserve Bank of India (central bank), general banking business } \\
\text { consisting of receipts, collections, payments and remittances on behalf } \\
\text { of Central Government is carried on by the Reserve Bank of India as its } \\
\text { Banker. At places where the branches of Reserve Bank of India does not } \\
\text { exist, the banking business of line Ministries is handled by the } \\
\text { commercial banks (which include both State-owned and private banks) } \\
\text { as agents of the Reserve Bank of India on turn over commission basis. } \\
\text { At the federal government level, the TSA main account at the Reserve } \\
\text { Bank of India is supplemented by subsidiary ledger accounts to record } \\
\text { and control payments attributable to individual line ministries. The } \\
\text { transaction banking services (for both revenue collection and payment } \\
\text { disbursement) is mainly provided by a number of commercial banks, and } \\
\text { the transaction accounts in these banks are operated on a zero-balance } \\
\text { basis and set-off at the end of the business day with the respective sub- } \\
\text { account of the TSA. }\end{array}$ & $\begin{array}{l}\text { Federal and } \\
\text { State } \\
\text { governments }\end{array}$ & $\begin{array}{l}\text { A mix of } \\
\text { centralized } \\
\text { and } \\
\text { decentralized } \\
\text { architecture, } \\
\text { with sub- } \\
\text { accounts for } \\
\text { line ministries } \\
\text { maintained at } \\
\text { the central } \\
\text { bank. }\end{array}$ & $\begin{array}{l}\text { Revenue } \\
\text { collection and } \\
\text { payment } \\
\text { disbursements } \\
\text { are mainly } \\
\text { conducted } \\
\text { through } \\
\text { commercial } \\
\text { banks (both } \\
\text { State-owned } \\
\text { and private). }\end{array}$ & $\begin{array}{l}\text { IFMIS at } \\
\text { federal level }\end{array}$ \\
\hline Indonesia & $\begin{array}{l}\text { New government regulations on cash management were adopted in July } \\
2007 \text {, which provided a strong legal basis for the rationalization of } \\
\text { government banking arrangements. The number of bank accounts } \\
\text { outside DG Treasury control has been reduced. A census of government } \\
\text { bank accounts in } 2007 \text { revealed some } 39,500 \text { government bank } \\
\text { accounts of which some } 6,000 \text { government bank accounts were closed } \\
\text { by mid-2009. The balances of revenue and expenditure accounts under } \\
\text { the control of DG Treasury and its regional network of } 178 \text { field offices } \\
\text { (KPPNs) are zero-balanced at the end of each working day and swept } \\
\text { into the TSA. The main exceptions are the accounts for salaries, where } \\
\text { KPPNs' bank accounts are credited one (previously three) day in } \\
\text { advance and the accounts of some ministries. For revenue accounts, the } \\
\text { zero-balancing principle was fully implemented in } 2009 \text {. All accounts of } \\
\text { autonomous government agencies are not yet integrated into the TSA. In } \\
\text { early 2009, a memorandum of understanding (MoU) between the Bank } \\
\text { of Indonesia (BI) and the MoF was signed regarding the rate of }\end{array}$ & $\begin{array}{l}\text { National } \\
\text { government }\end{array}$ & $\begin{array}{l}\text { Decentralized } \\
\text { architecture }\end{array}$ & & $\begin{array}{l}\text { An IFMIS is } \\
\text { under } \\
\text { development. }\end{array}$ \\
\hline
\end{tabular}




\begin{tabular}{|c|c|c|c|c|c|}
\hline & $\begin{array}{l}\text { remuneration of government deposits held in the main treasury account } \\
\text { at } \mathrm{BI} \text { (the RKUN account) in either overnight, deposit on-call or time } \\
\text { deposit accounts, with implementation as from January 1, 2009. A new } \\
\text { information system is being developed (SPAN). }\end{array}$ & & & & \\
\hline Cambodia & $\begin{array}{l}\text { Significant progress has been made to reduce and consolidate } \\
\text { government bank accounts at the National Bank of Cambodia (NBC) to } \\
\text { establish a TSA. Only } 16 \text { of the } 174 \text { frozen 'current' bank accounts (of } \\
\text { various line agencies) at NBC remain to be consolidated with the TSA } \\
\text { (November 2009). 'Current' accounts exclude many donor project } \\
\text { (investment), 'earmarked' fund, and budget support accounts, as well as } \\
\text { salary accounts with the ANZ Royal Bank (a commercial bank), which } \\
\text { are being operated as separate accounts outside the TSA. As of October } \\
2009 \text {, there were reportedly } 412 \text { bank accounts at NBC and } 36 \text { bank } \\
\text { accounts at ANZ Royal Bank, which are not yet integrated into the TSA. } \\
\text { A pilot scheme in two provinces (out of } 24 \text { ) to use commercial banks for } \\
\text { treasury banking services commenced in } 2009 \text {. }\end{array}$ & $\begin{array}{l}\text { A TSA at } \\
\text { national level is } \\
\text { being } \\
\text { established. }\end{array}$ & $\begin{array}{l}\text { Decentralized } \\
\text { architecture }\end{array}$ & & No \\
\hline \multicolumn{6}{|c|}{ TSA Models in African Countries Adapted fRom the French Model } \\
\hline Country & Description & Coverage & $\begin{array}{c}\text { Degree of } \\
\text { Centralization }\end{array}$ & $\begin{array}{l}\text { Role of } \\
\text { Commercial } \\
\text { Banks }\end{array}$ & $\begin{array}{c}\text { Availability } \\
\text { of IFMIS }\end{array}$ \\
\hline $\begin{array}{l}\text { Various } \\
\text { African } \\
\text { countries }\end{array}$ & $\begin{array}{l}\text { The African countries using the French legal framework of } 1959 \\
\text { (l'ordonnance de 1959) organize their cash management systems } \\
\text { according to the principle of a TSA (compte unique du Trésor), which is } \\
\text { managed by the respective central banks. However, these countries did } \\
\text { not have the equivalent system of "treasury correspondents" (which } \\
\text { existed in France until 1990s), and experienced severe cash shortfalls } \\
\text { as a result of their debt burden and also due to high petroleum prices } \\
\text { during the 1970s. This gave rise to the practice of bypassing the TSA } \\
\text { during the years 1980-2000, leading to a proliferation of special accounts } \\
\text { and funds (comptes et fonds spéciaux), deposited outside the TSA. The } \\
\text { cash shortfall problem in these countries also had the effect of freezing } \\
\text { the deposits from correspondents and the public, rendering the deposits } \\
\text { in Caisses d'épargne and the Postal department illiquid. Under the IMF- } \\
\text { led PRGF programs that followed, the situation in these countries } \\
\text { improved somewhat with the use of the TSA for payment of } \\
\text { salaries/wages and progressively for other categories of payments. } \\
\text { However, the payments for expenditure financed by donors were often } \\
\text { outside the control of both the treasury and the TSA. Such difficulties } \\
\text { remain for a number of francophone African countries, such as Guinée } \\
\text { Bissau, the Central African Republic (RCA), Tchad and the Republic of } \\
\text { Congo, inhibiting the progress toward an efficient cash management }\end{array}$ & $\begin{array}{l}\text { The coverage, } \\
\text { in principle, is } \\
\text { for the whole of } \\
\text { national } \\
\text { government. In } \\
\text { practice, } \\
\text { several special } \\
\text { accounts have } \\
\text { been opened } \\
\text { outside the } \\
\text { TSA. Donor- } \\
\text { funded } \\
\text { operations also } \\
\text { remain outside } \\
\text { the TSA. }\end{array}$ & $\begin{array}{l}\text { Centralized in } \\
\text { principle. } \\
\text { However, } \\
\text { special } \\
\text { payment } \\
\text { procedures in } \\
\text { vogue in } \\
\text { several } \\
\text { countries have } \\
\text { diluted the } \\
\text { treasury } \\
\text { control over } \\
\text { payments. }\end{array}$ & $\begin{array}{l}\text { In the case of } \\
\text { countries } \\
\text { affiliated to a } \\
\text { regional central } \\
\text { bank (such as } \\
\text { BCEAO and } \\
\text { BEAC), the } \\
\text { authorities tend } \\
\text { to rely on local } \\
\text { commercial } \\
\text { banks to provide } \\
\text { specific } \\
\text { solutions }\end{array}$ & $\begin{array}{l}\text { Most of these } \\
\text { countries are } \\
\text { yet to have } \\
\text { fully functional } \\
\text { IFMIS. }\end{array}$ \\
\hline
\end{tabular}




\begin{tabular}{|l|l|l|l|}
\hline system based on a TSA. & $\begin{array}{l}\text { One should distinguish between two categories of African countries } \\
\text { following the French model: (i) countries participating in the FCFA zone } \\
\text { with one respective regional central bank (BCEAO or BEAC); and (ii) } \\
\text { countries outside the FCFA zone having their own national central } \\
\text { banks. In terms of managing a TSA, it is clear that national central banks } \\
\text { provide a more flexible environment compared to regional central banks, } \\
\text { which have stricter rules for the purpose (and thus the authorities tend to } \\
\text { rely on local commercial banks to provide specific solutions to budget } \\
\text { management problems). On the other hand, in many of these countries, } \\
\text { the boundary between the treasury and the national central banks is not } \\
\text { clearly defined, with the latter exercising some treasury functions, } \\
\text { including making direct payments for government expenditures in certain } \\
\text { cases. Such practices complicate both budget and cash management. }\end{array}$
\end{tabular} \mid

${ }^{1}$ Some of the countries listed in this table (particularly under the groupings Latin American and ECA countries) are in the process of establishing a TSA and, therefore, do not have a full TSA as yet. ${ }^{2}$ There are a few exceptions: some small funds and the financial operations of the national assembly are administered outside the TSA regime. 


\section{APPENDIX II. INTERBANK PAYMENT AND SETTLEMENT SySTEMS ${ }^{34}$}

Interbank payment and settlement systems around the world are undergoing fundamental changes, which are making treasury management more efficient and more secure. Paper checks and cash are being replaced by electronic means. The institutional environment in which the payment systems operate, including the degree of development of the interbank money market and the sophistication of participants' treasury management, has been determinant in this trend.

Interbank payment systems can be classified as (i) wholesale (large value), and (ii) retail and small value systems. Each payment system uses different settlement systems. Also, payment systems either settle immediately on a gross basis or after some delay on a net basis.

Large Value (Wholesale) Payment Systems (LVPS). There are three main types:

(i) Deferred Net Settlement (DNS) systems: they create intraperiod risks, which explain why they are now used by most countries usually for low-value payments; (ii) Real-Time Gross Settlement (RTGS) systems: they eliminate many of the intraday and participant settlement risks associated with net settlement; and (iii) Hybrids, such as Continuous Net Settlement (CNS) and queue-augmented RTGS, which redesign DNS and RTGS systems to reduce risk.

The risk and costs in DNS systems led to the adoption of RTGS in all EU and most G-20 countries. TARGET, the Fed's Fedwire, and the Bank of England's CHAPS Sterling are the largest LVPS. The three systems are operated by their central banks. Given that the central banks guarantee payment, there is no settlement risk to the participants. Fedwire is also used for the settlement of U.S. government securities

Retail and Small Value Payment Systems (SVPS). The structure of retail and SVPS still differs substantially among countries. In many, only private entities provide clearing services, while in some, central bank services coexist with private suppliers. However, after multilateral clearing, settlement usually takes place at the end of the day through accounts held at the central bank.

As mentioned above, an important trend in SVPS has been the shift from cash and paperbased instruments to electronic payment methods. In addition, there has been an increase in straight through processing (STP) due to enhanced interoperability of payment procedures based on common data protocols.

An example of an SVPS is the Automated Clearing House (ACH) network in the U.S., which handles repetitive batch transactions, such as payroll, pension, and annuity payments (credits), and collection of insurance premiums, and utility bills.

\footnotetext{
${ }^{34}$ Source: Schmitz, Stefan W. and Geoffrey E. Wood, 2006.
} 


\section{REFERENCES}

Dener, Cem, 2007, Treasury Single Account Practices in ECA, mimeo.

Economist Intelligence Unit (EIU), 2005, “Assessing Payments Systems in Latin America," The Economist.

Garbade, Kenneth, John C. Partlan, and Paul J. Santoro, 2004, "Recent Innovations in Treasury Cash Management," Current Issues in Economics and Finance, Vol. 10, No. 11 (November).

Horcher, Karen A., 2006, Essentials of Managing Treasury, John Wiley \& Sons, Inc. , 2006, Essentials of Managing Cash, John Wiley \& Sons, Inc.

Larson, M. Corinne, 2007, "Local Government Cash Management," Chapter 2 in Local Public Financial Management, ed. by Anwar Shah, The World Bank.

Lienert, Ian, 2009, Modernizing Cash Management, Technical Notes and Manuals, Fiscal Affairs Department (Washington: International Monetary Fund).

Schmitz, Stefan W. and Geoffrey E. Wood, 2006, "Institutional Change in the Payments Systems and Monetary Policy-An Introduction," in Institutional Change in the Payment System and Monetary Policy, ed. by Stefan W. Schmitz and Geoffrey E. Wood (Routledge).

Ter-Minassian, Teresa and Pedro Parente, 1995, "Setting Up a Treasury in Economies in Transition,” IMF Working Paper 95/16 (Washington: International Monetary Fund).

White, Lawrence H., 2006, "Payments System Innovations in the United States since 1945 and their Implications for Monetary Policy," Chapter 1 in Institutional Change in the Payment System and Monetary Policy, ed. by Stefan W. Schmitz and Geoffrey E. Wood (Routledge). 